\title{
A taxonomic revision and molecular phylogeny of the eastern Palearctic species of the genera Schizomyia Kieffer and Asteralobia Kovalev (Diptera, Cecidomyiidae, Asphondyliini), with descriptions of five new species of Schizomyia from Japan
}

\author{
Ayman Khamis Elsayed ${ }^{1,2,3}$, Junichi Yukawa ${ }^{4}$, Makoto Tokuda ${ }^{1,2}$
}

I The United Graduate School of Agricultural Sciences, Kagoshima University, Kagoshima 890-0065, Japan 2 Laboratory of Systems Ecology, Faculty of Agriculture, Saga University, Saga 840-8502, Japan 3 Department of Applied Entomology, Faculty of Agriculture, Alexandria University, Alexandria, Egypt 4 Entomological Laboratory, Faculty of Agriculture, Kyushu University, Fukuoka 819-0395, Japan

Corresponding author: Ayman Khamis Elsayed (ayman.khamis77@gmail.com)

Academic editor: Netta Dorchin | Received 11 September 2018 | Accepted31 October 2018 | Published 18 December 2018

http://zoobank.org/738D225C-84B9-4E64-ADOD-FD0D46531B46

Citation: Elsayed AK, Yukawa J, Tokuda M (2018) A taxonomic revision and molecular phylogeny of the eastern Palearctic species of the genera Schizomyia Kieffer and Asteralobia Kovalev (Diptera, Cecidomyiidae, Asphondyliini), with descriptions of five new species of Schizomyia from Japan. ZooKeys 808: 123-160. https://doi.org/10.3897/ zookeys.808.29679

\begin{abstract}
The genus Asteralobia (Diptera, Cecidomyiidae, Asphondyliini, Schizomyiina) was erected by Kovalev (1964) based on the presence of constrictions on the cylindrical male flagellomeres. In the present study, we examine the morphological features of Asteralobia and Schizomyia and found that the male flagellomeres are constricted also in Schizomyia galiorum, the type species of Schizomyia. Because no further characters clearly separating Asteralobia from Schizomyia were observed, we synonymize Asteralobia under Schizomyia. Molecular phylogenetic analysis strongly supports our taxonomic treatment. We describe five new species of Schizomyia from Japan, S. achyranthesae Elsayed \& Tokuda, sp. n., S. diplocyclosae Elsayed \& Tokuda, sp. n., S. castanopsisae Elsayed \& Tokuda, sp. n., S. usubai Elsayed \& Tokuda, sp. n., and S. paederiae Elsayed \& Tokuda, sp. n., and redescribe three species, S. galiorum Kieffer, S. patriniae Shinji, and $S$. asteris Kovalev. A taxonomic key to the Japanese Schizomyia species is provided.
\end{abstract}

\section{Keywords}

Cecidomyiinae, gall midges, Schizomyiina, taxonomic key

Copyright Ayman Khamis Elsayed et al. This is an open access article distributed under the terms of the Creative Commons Attribution License (CC BY 4.0), which permits unrestricted use, distribution, and reproduction in any medium, provided the original author and source are credited. 


\section{Introduction}

Schizomyia Kieffer is a cosmopolitan genus of the subtribe Schizomyiina (Diptera, Cecidomyiidae, Cecidomyiinae, Asphondyliini) with 53 species associated with diverse plant families (Gagné and Jaschhof 2017, Elsayed et al. in press). The genus includes species with needle-like ovipositors, four-segmented palpi, and larval terminal segments with four or fewer pairs of terminal papillae (Gagné and Menjivar 2008). Most of these species induce bud galls, but some induce leaf galls (Gagné 1989). Some Schizomyia species are agricultural pests, e.g. S. loroco Gagné, which induces flower galls on loroco, Fernaldia pandurata (A. DC.) Woodson (Apocynaceae), in El Salvador (Gagné and Menjivar 2008). A few species have been used as potential biological control agents, e.g., S. macrofila (Felt), which induces flower galls on Amsinckia spp. weeds in California (Pantone and Brown 1985).

Kovalev (1964), in his revision of the Russian Far East gall midges of the tribe Asphondyliini, erected the genus Asteralobia based on the presence of shallow or deep constrictions on the cylindrical male flagellomeres. Although Asteralobia has been treated as an independent genus of Schizomyiina and presently contains 12 species (Gagné and Jaschhof 2017), some studies have indicated that Asteralobia could be subsumed under Schizomyia because of the lack of known synapomorphic differences between them (e.g. Tokuda et al. 2003; Gagné and Jaschhof 2017). In the present study, we re-examined morphological features of Asteralobia and Schizomyia and analyzed molecular phylogenetic relationships between them, which have led us to the conclusion that Asteralobia should be synonymized under Schizomyia. In addition, we describe five new species of Schizomyia from Japan and provide a taxonomic key to the Schizomyia species from Japan.

\section{Materials and methods}

\section{Collecting and rearing methods}

Galls induced by six gall midge species were collected from various localities in Japan (Table 1). Some galls were dissected to obtain larval specimens, while the remaining galls were kept in plastic bags until the departure of mature larvae from the galls. Thereafter, larvae were transferred to plastic cups (120 $\mathrm{mm}$ in diameter, $110 \mathrm{~mm}$ in depth) containing a mixture of wet peat moss and sand (1:1), covered with fine mesh, and fixed with a rubber band. Cups containing larvae obtained from fruit galls on Achyranthes bidentata Blume (Amaranthaceae) and Trachelospermum asiaticum (Sieb. et Zucc.) Nakai (Apocynaceae), and flower bud galls on Paederia foetida L. (Rubiaceae) and Patrinia villosa (Thunb.) (Valerianaceae) were transferred to the field on the Saga University campus, Saga Prefecture (about $5.5 \mathrm{~m}$ a.s.l.), and half-buried in the soil to allow the mature larvae to overwinter under natural conditions. These cups were brought back to the laboratory in April to rear adults and were kept at room temperature. In cases of larvae obtained from flower bud galls on Diplocyclos palmatus (L.) Jeffrey (Cucurbitaceae) and Castanopsis sieboldii (Makino) Hatus. (Fagaceae), the cups containing larvae were maintained at room temperature in the laboratory until adult emergence. 
Table I. Collection data of the newly described and redescribed Japanese Schizomyia species.

\begin{tabular}{|c|c|c|c|c|}
\hline Gall midge & $\begin{array}{l}\text { Host Plant and } \\
\text { galls }\end{array}$ & Collection site & $\begin{array}{c}\text { Collecting } \\
\text { date }\end{array}$ & Collector \\
\hline \multirow[t]{7}{*}{$\begin{array}{l}\text { Schizomyia } \\
\text { achyranthesae sp. n. }\end{array}$} & \multirow{7}{*}{$\begin{array}{l}\text { Fruit bud galls } \\
\text { on Achyranthes } \\
\text { bidentata Blume } \\
\text { (Amaranthaceae) }\end{array}$} & $\begin{array}{c}\text { Tokushima City, Tokushima } \\
\text { Prefecture }\end{array}$ & $\begin{array}{l}6 \text { October } \\
2001\end{array}$ & M. Yukinari \\
\hline & & $\begin{array}{c}\text { Kyushu University, Ito } \\
\text { Campus, Fukuoka Prefecture }\end{array}$ & $\begin{array}{l}30 \text { October } \\
2012\end{array}$ & J. Yukawa et al. \\
\hline & & $\begin{array}{c}\text { Mount Hinokuma, Saga } \\
\text { Prefecture }\end{array}$ & $\begin{array}{l}16 \text { October } \\
2014\end{array}$ & A.K. Elsayed \& M. Tokuda \\
\hline & & Mount Tara, Saga Prefecture & $\begin{array}{l}22 \text { October } \\
2014\end{array}$ & A.K. Elsayed \& M. Tokuda \\
\hline & & $\begin{array}{l}\text { Mount Tenzan, Saga } \\
\text { Prefecture }\end{array}$ & $\begin{array}{l}29 \text { October } \\
2001\end{array}$ & A.K. Elsayed \& M. Tokuda \\
\hline & & Mount Tara, Saga Prefecture & $\begin{array}{l}9 \text { October } \\
2015\end{array}$ & M. Tokuda \\
\hline & & Takeo City, Saga Prefecture & $\begin{array}{l}10 \text { October } \\
2015\end{array}$ & A. Kita \\
\hline \multirow[t]{4}{*}{$\begin{array}{l}\text { Schizomyia } \\
\text { diplocyclosae sp. } \mathrm{n} .\end{array}$} & \multirow{4}{*}{$\begin{array}{l}\text { Flower bud galls } \\
\text { on Diplocyclos } \\
\text { palmatus (L.) Jeffrey } \\
\text { (Cucurbitaceae) }\end{array}$} & $\begin{array}{l}\text { Kinjo town, Naha City, } \\
\text { Okinawa Prefecture }\end{array}$ & $\begin{array}{l}13 \text { January } \\
1977\end{array}$ & S. Yamauchi \\
\hline & & $\begin{array}{c}\text { Shuri, Naha City, Okinawa } \\
\text { Prefecture }\end{array}$ & January 1977 & S. Yamauchi \\
\hline & & $\begin{array}{c}\text { Gogayama, Nakijin village, } \\
\text { Okinawa Prefecture }\end{array}$ & 4 March 2002 & M. Tokuda \\
\hline & & $\begin{array}{c}\text { Hantagawa, Naha City, } \\
\text { Okinawa Prefecture }\end{array}$ & $\begin{array}{l}10 \text { February } \\
2016\end{array}$ & T. Ganah-Kikumura \\
\hline \multirow[t]{2}{*}{$\begin{array}{l}\text { Schizomyia } \\
\text { paederiae sp. n. }\end{array}$} & \multirow[t]{2}{*}{$\begin{array}{l}\text { Flower bud galls on } \\
\text { Paederia foetida } \mathrm{L} \text {. } \\
\quad \text { (Rubiaceae) }\end{array}$} & $\begin{array}{c}\text { Nishino-omote, Nishino- } \\
\text { omote City, Nokubi, } \\
\text { Kagoshima Prefecture }\end{array}$ & $\begin{array}{l}24 \text { September } \\
2014\end{array}$ & K. Ogata \\
\hline & & $\begin{array}{l}\text { Ogorori City, Misawa, } \\
\text { Aomori Prefecture }\end{array}$ & August 2016 & K. Matsunaga \\
\hline $\begin{array}{l}\text { Schizomyia } \\
\text { patriniae (Shinji } \\
\text { 1938) }\end{array}$ & $\begin{array}{l}\text { Flower bud } \\
\text { galls on Patrinia } \\
\text { villosa (Thunb.) } \\
\text { (Valerianaceae) }\end{array}$ & $\begin{array}{c}\text { Kyuragi, Karatsu City, Saga } \\
\text { Prefecture }\end{array}$ & $\begin{array}{l}12 \text { October } \\
2015\end{array}$ & M. Tokuda \\
\hline \multirow[t]{4}{*}{$\begin{array}{l}\text { Schizomyia } \\
\text { castanopsisae sp. n. }\end{array}$} & \multirow{4}{*}{$\begin{array}{l}\text { Flower bud galls on } \\
\text { Castanopsis sieboldii } \\
\text { (Fagaceae) }\end{array}$} & Hachijojima Island & $\begin{array}{l}6 \text { December } \\
2014\end{array}$ & T. Kikuchi \\
\hline & & Shikinejima Island & $\begin{array}{l}10 \text { December } \\
2014\end{array}$ & M. Tokuda \\
\hline & & Niijima Island & $\begin{array}{l}11 \text { December } \\
2014\end{array}$ & M. Tokuda \\
\hline & & The Izu Islands & $\begin{array}{l}9 \text { December } \\
2016\end{array}$ & M. Tokuda \\
\hline \multirow[t]{4}{*}{$\begin{array}{l}\text { Schizomyia usubai } \\
\text { sp. n. }\end{array}$} & \multirow{4}{*}{$\begin{array}{l}\text { Fruit galls on } \\
\text { Trachelospermum } \\
\text { asiaticum (Sieb. } \\
\text { et Zucc.) Nakai } \\
\text { (Apocynaceae) }\end{array}$} & $\begin{array}{c}\text { Mount Takakuma, } \\
\text { Kagoshima Pref. }\end{array}$ & $\begin{array}{c}\text { November } \\
1969\end{array}$ & J. Yukawa \\
\hline & & $\begin{array}{l}\text { Imuta Lake-side, Kedouin } \\
\text { Town, Kagoshima Prefecture }\end{array}$ & $\begin{array}{c}2 \text { November } \\
1978\end{array}$ & S. Sako \\
\hline & & $\begin{array}{l}\text { Torinosu, Tanabe City, } \\
\text { Wakayama Prefecture }\end{array}$ & $\begin{array}{l}2 \text { November } \\
2016\end{array}$ & I. Matoba \\
\hline & & $\begin{array}{c}\text { Mount Onigasawa, Nishino- } \\
\text { omote, Nishino-omote City, } \\
\text { Kagoshima Prefecture }\end{array}$ & $\begin{array}{l}4 \text { November } \\
2016\end{array}$ & K. Ogata \\
\hline
\end{tabular}

The pupal exuviae protruding from the surface of the soil in the plastic cups were collected at the same time carefully. Reared specimens were preserved in $75 \%$ ethanol for morphological study and $99.5 \%$ ethanol for the molecular phylogenetic study. 


\section{Taxonomy}

Gall midge specimens were mounted on slides in Canada balsam using the technique outlined in Gagné (1994), except for the clearing step following Elsayed et al. (2018). The slide-mounted specimens were examined under a bright-field and phase-contrast microscope (H550L, Nikon, Tokyo) and illustrations were made with the aid of a drawing tube. A semi-motorized fluorescence microscope (BX53, Olympus, Tokyo) was used to photograph some of the characters from mounted specimens with the aid of a microscope-attached camera (DP22, Olympus, Tokyo).

Morphological terminology basically follows McAlpine et al. (1981) for adults, but the thoracic sclerite "mesanepisternum" follows Gagné (1968) and the wing venation follows Yukawa (1971). Larval and pupal terminology follows Gagné (1994). All the types of the newly described species are deposited in the collection of the Entomological Laboratory, Faculty of Agriculture, Kyushu University, Japan (KUEC).

Adult and immature specimens of Asteralobia humuli Shinji, A. patriniae Shinji, $A$. sasakii Monzen and $A$. soyogo Kikuti, and larvae of $A$. doellingeriae Kovalev were examined in KUEC. Adults of $A$. asteris Kovalev, $A$. calathidiphaga Kovalev, A. doellingeriae, and $A$. solidaginis Kovalev, as well as four females and two males of $S$. galiorum were examined in the B. M. Mamaev Collection in the Museum of Nature and Human Activities, Hyogo, Japan. A female and a pupa of Schizomyia galiorum Kieffer were examined in the National Museum of Natural History, Smithsonian Institution, Washington, DC, USA (USNM).

\section{Molecular phylogenetic study}

Total DNA was extracted from larval or adult specimens and fragments of the mitochondrial genes, cytochrome oxidase subunit I (COI) and $12 \mathrm{~S}$ small ribosomal subunit, were sequenced and aligned following Elsayed et al. (2017). The following sets of primers were used for the cytochrome oxidase subunit I (COI) gene: J-1718 (5'GGA GGA TTT GGA AAT TGA TTA GTT CC-3') (Simon et al. 1994) and COIA (5'-CCC GGT AAA ATT AAA ATA TAA ACT TC-3') (Funk et al. 1995); COIS (5-GGA TCA CCT GAT ATA GCA TTC CCA TAT TGG-3') and COIA (5'-CCC GGT AAA ATT AAA ATA TAA ACT TC-3’) (Funk et al., 1995); or LCO1490 (5'GGT CAA CAA ATC ATA AAG ATA TTG G-3') and HCO2198 (5'-TAA ACT TCA GGG TGA CCA AA AAT CA-3') (Folmer et al. 1994). The following primer set was used for the $12 \mathrm{~S}$ small ribosomal subunit gene: SR-J-14199 (5'-TAC TAT GTT ACG ACT TAT-3') and SR-N-14594 (5'-AAA CTA GGA TTA GAT ACC C-3’) (Kambhampati and Smith 1995). The obtained sequences were deposited in the DNA Data Bank of Japan (DDBJ), the European Molecular Biology Laboratory (EMBL), and GenBank under the accession numbers given in Table 2.

The sequence data were analyzed with the maximum likelihood (ML) method using MEGA (ver. 6.0) (Tamura et al. 2013). Sequences of Asphondylia gennadii Marchal 


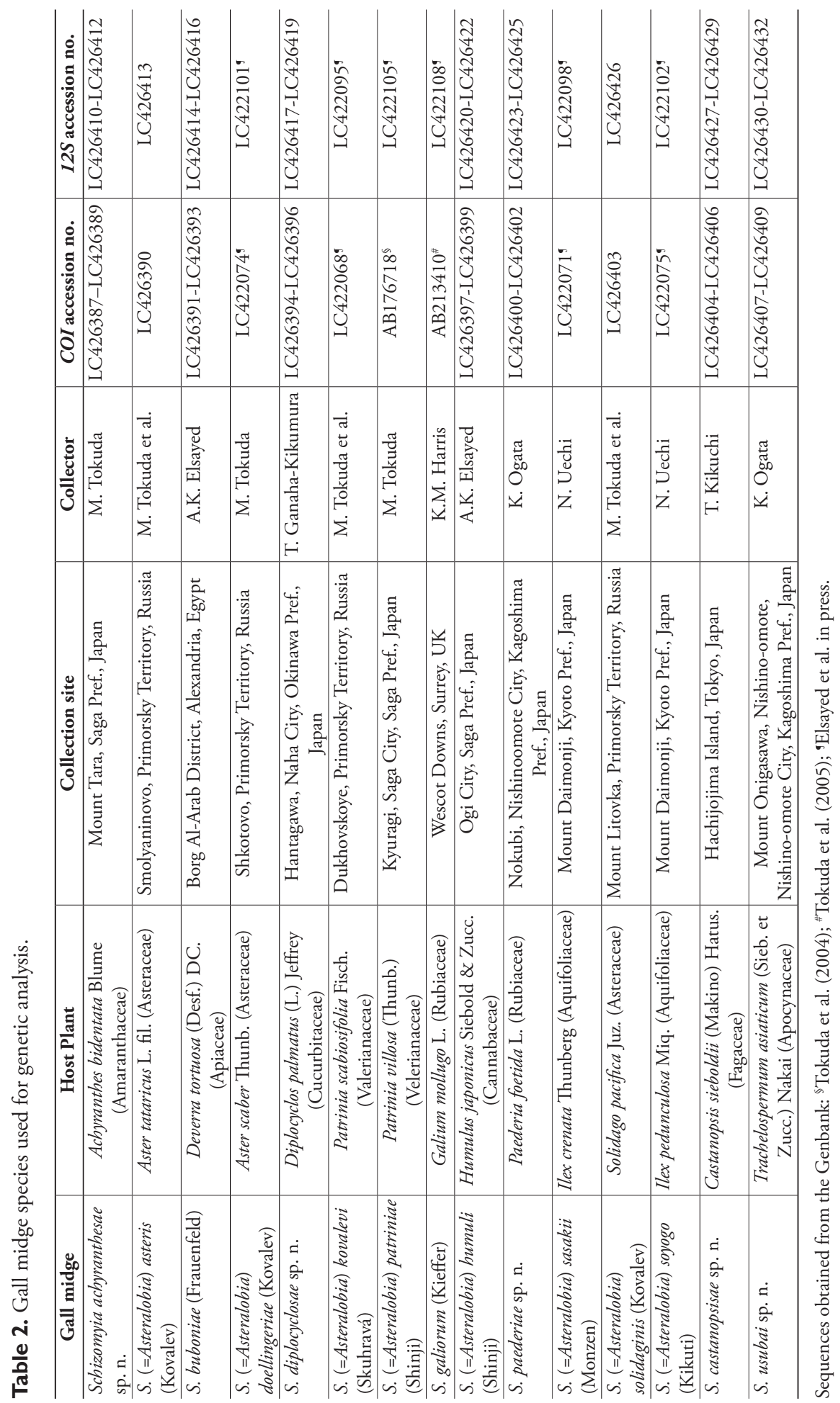


(AB198012 and AB115580) and Pseudasphondylia neolitseae Yukawa (AB334237 and LC422092) were used as outgroup species. The best model was identified with the jModelTest 2 software (Darriba et al. 2012, Guindon and Gascuel 2003) on the basis of hierarchical likelihood ratio tests (hLRT) was GTR+G+I.

\section{Results}

\section{Taxonomy}

\section{Genus Schizomyia Kieffer, 1889}

Schizomyia Kieffer, 1889: 183. Type species: S. galiorum Kieffer, 1889.

Parasphondylia Kieffer, 1913: 93. Type species: P. variicornis Kieffer, 1913. Asteralobia Kovalev, 1964: 419. Type species: A. doellingeriae Kovalev, 1964. Syn. n. Euasteralobia Kovalev, 1964: 430, as subg. of Asteralobia. Type species, Asteralobia calathidiphaga Kovalev (mon.).

Kovalev (1964) erected the genus Asteralobia, all occurring in Russian Far East and Japan, based on the presence of constrictions on male flagellomeres. However, this character is observed in the type species of Schizomyia, S. galiorum (Fig. 69), and no other characters were found to differentiate between these genera. Therefore, the 12 species of Asteralobia, namely $A$. asteris Kovalev, A. calathidiphaga Kovalev, A. clematidis Fedotova, $A$. doellingeriae Kovalev, A. humuli Shinji, A. kovalevi Skuhravá, $A$. patriniae Shinji, $A$. sasakii Monzen, $A$. soyogo Kikuti, $A$. solidaginis Kovalev, $A$. spiraeae Fedotova and $A$. veronicastrum Fedotova, are combined here under Schizomyia.

Schizomyia is a cosmopolitan genus of 53 species, which are associated with over 30 host plants (Gagné and Jaschhof 2017; Elsayed et al. in press). With such a broad host range, Schizomyia is considered a catch-all genus defined only by plesiotypic characters and lack of synapomorphies (Gagné and Marohasy 1997; Gagné 1994). However, Schizomyia can be distinguished from the other genera of Schizomyiina by the following combination of characters: palpi four-segmented; tarsomeres I without ventroapical extension (Elsayed et al. in press), except $S$. maricaensis Sousa \& Maia (Sousa and Maia 2007) and S. novoguineensis Kolesik (Kolesik and Butterill 2015); ovipositor protrusible, with needlelike protrusible portion; and larva usually with bilobed spatula and eight or fewer terminal papillae.

\section{Schizomyia achyranthesae Elsayed \& Tokuda, sp. n.} http://zoobank.org/AC909591-4D08-489E-AC19-9221F770F0D6 Figs 5-17; Table $S 1$

Etymology. The species name, achyranthesae, is based on the generic name the host plant, Achyranthes bidentata (Amaranthaceae). 

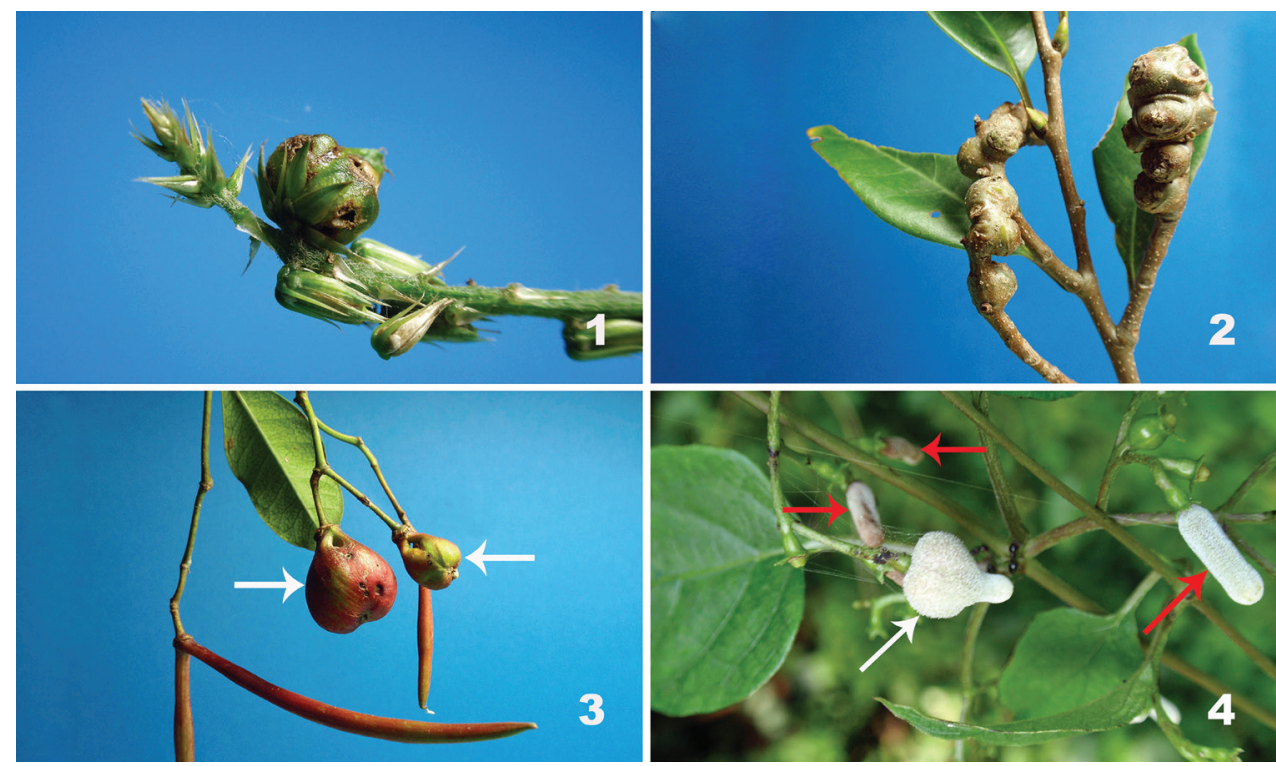

Figures I-4. Galls of Schizomyia spp. I Fruit gall induced by S. achyranthesae on Achyranthes bidentata (Amaranthaceae) $\mathbf{2}$ Inflorescence galls induced by S. castanopsisae on Castanopsis sieboldii (Fagaceae) $\mathbf{3}$ Fruit galls (arrows) induced by S. usubai on Trachelospermum asiaticum (Apocynaceae) 4 A flower bud gall (white arrow) induced by $S$. paederiae on Paederia foetida (Rubiaceae) [red arrows indicate normal flower buds].

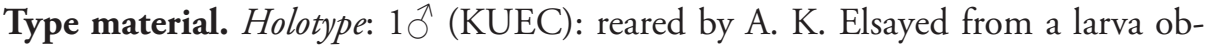
tained from a fruit gall on A. bidentata, collected from Mount Tara, Saga Prefecture, Japan, on 7.x.2015, M. Tokuda leg., the larva departed from gall between 10-19.x.2015 and the adult male emerged on 3.ix.2016. Paratypes: All paratypes were reared from fruit galls on $A$. bidentata in Japan. 3 larvae: collected from Tokushima City, Tokushima Prefecture on 6.x.2001, M. Yukinari leg., larvae departed from galls on 12.x.2001; 5 larvae: collected from Tokushima City, Tokushima Prefecture on 30.x.2012, J. Yukawa et al. leg., larvae departed from galls on 30.x.2012; 8 \% 4 Pupal exuviae: collected from Takeo City, Saga Prefecture on 10.x.2015, A. Kita leg., larvae departed from galls between 13-19.x.2015, adults emerged on 1.ix.2016; 3 : : collected from Mount Hinokuma, Saga Prefecture on 16.x.2014, A. K. Elsayed \& M. Tokuda leg., larvae departed from galls on 22.x.2014, adults emerged in summer 2015; 4 pupal exuviae: collected from Takeo City, Saga Prefecture on 10.x.2015, larvae departed from galls between 13-19.x.2015, adults emerged on 29.viii.2016; 10今, 60: same data as holotype.

Description. Head (Fig. 5): Compound eyes separated on vertex by a diameter of $0.0-0.75$ facets, eye bridge $7-8$ facets long, facets hexagonal. Fronto-clypeus with 15-21 setae $(n=6)$. Labrum and labella setose. Palpus 4-segmented: first segment ca $34 \mu \mathrm{m}$, second 1.3 times as long as the first, third 1.5 as long as the second, fourth 1.3 as long as the third. Antenna: scape slightly wider than long, pedicel rounded, flagellomeres I and II partially fused; female flagellomeres I-IX cylindrical with 2 connected rings of circumfila (Fig. 6); distal flagellomeres successively shorter; flagellomere $\mathrm{X}$ about as long as wide; flagellomere $\mathrm{XI}$ rounded, slightly wider than long; 


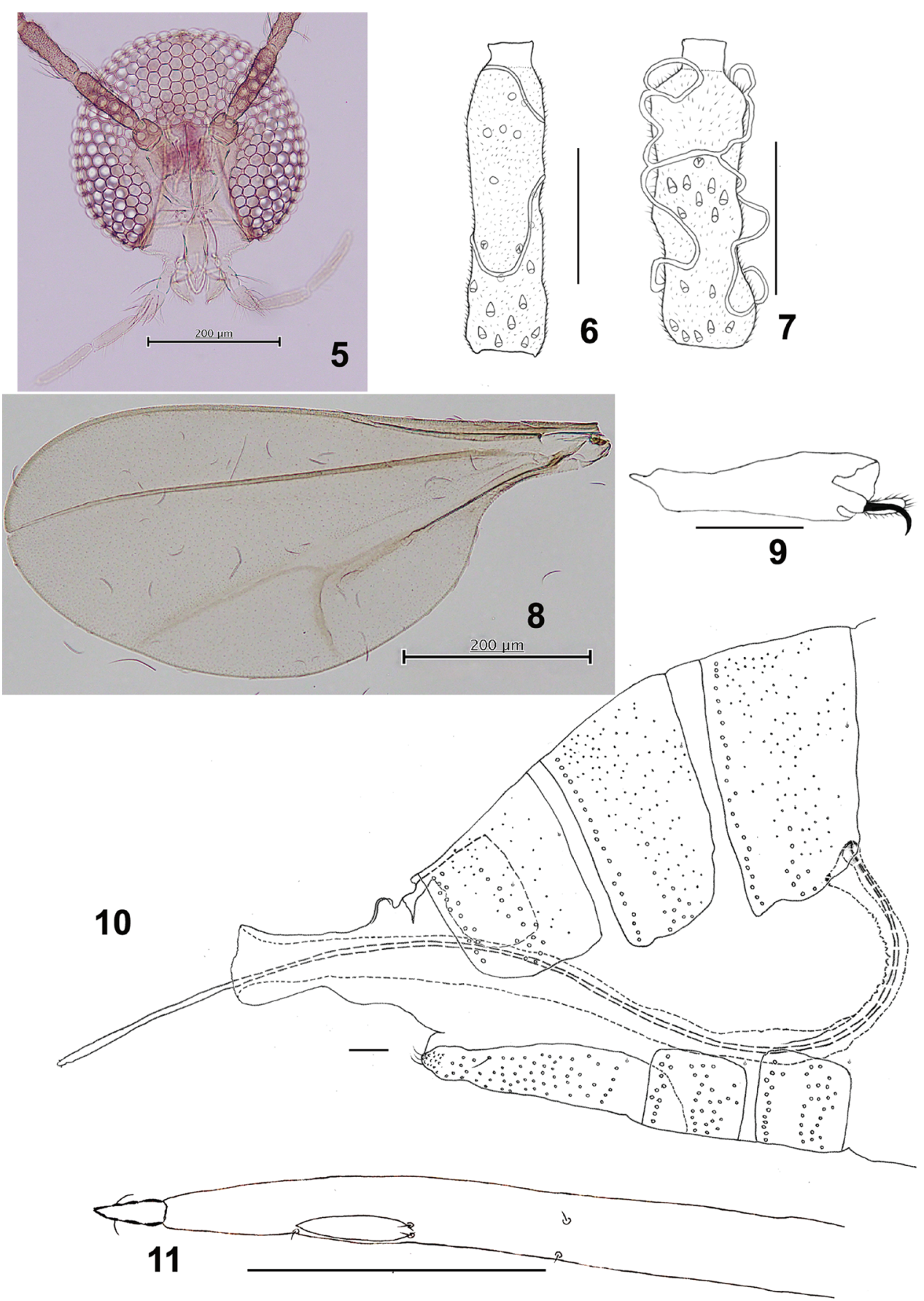

Figures 5-II. Schizomyia achyranthesae. 5 Head 6 Ventral view of female antennal flagellomere V 7 Ventral view of male flagellomere V 8 Wing 9 Tarsomere V and acromere $\mathbf{1 0}$ Terminal part of female abdomen I I Ovipositor apex. Scale bars: $50 \mu \mathrm{m}(\mathbf{6}, \mathbf{7}, \mathbf{9 - I}$ ) $), 200 \mu \mathrm{m}(\mathbf{5}, \mathbf{8})$. 
flagellomere XII rudimentary, partially fused with XI; male flagellomeres cylindrical with sinuous circumfila (Fig. 7).

Thorax: Wing (Fig. 8) length $1.60-2.02 \mathrm{~mm}(n=6)$ in female, $1.43-1.73 \mathrm{~mm}(n=$ 5) in male: $R_{1}$ join $C$ before wing midlength, $R_{5}$ join $C$ just after wing apex, $C$ broken after the conjunction with $\mathrm{R}_{5}$; wing fold present; $\mathrm{M}_{3+4}$ forked with $\mathrm{Cu}$. Tarsal claws untoothed, bent after midlength; empodia shorter than claws, with long setulae apically; pulvilli not discernable (Fig. 9). Anepimeral setae 19-23 $(n=8)$; mesanepisternum scales 22-38 $(n=6)$; lateral scutal setae 21-28 $(n=8)$. Lengths of leg segments as in Suppl. material 1: Table S1.

Female abdomen (Figs 10, 11): Tergites with anterior pair of trichoid sensilla; tergites I-VII rectangular and evenly covered with scales, tergites I-VI with a posterior row of setae and some scattered setae laterally at midlength; tergite VII with 1-2 posterior rows of setae and some scattered setae laterally at midlength; tergite VIII bare, notched laterally, posterior margin with a pair of well-developed dorsal lobes. Sternites II-VI rectangular, bare and less pigmented medially, with the lateral pair of trichoid sensilla situated anterior to the sclerotized sternite, several scattered setae on the anterior half, and 1-2 rows of setae posteriorly; sternite VII about 2.6 times as long as preceding sternites, with anterior pair of trichoid sensilla laterally situated on the sternite and setae covering posterior two-thirds. Ovipositor: protrusible needlelike portion about 4 times as long as sternite VII (Fig. 10); cerci fused, each lobe with few setae (Fig. 11).

Male abdomen: Tergites I-VII as in female; tergite VIII weakly sclerotized medially, with anterior pair of trichoid sensilla. Sternites II-VI as in female; sternite VII with lateral pair of trichoid sensilla situated anterior to the sclerotized sternite, several setae scattered anteriorly, median membranous bare area and 1-2 posterior row of setae; sternite VIII setose, with lateral pair of trichoid sensilla situated intersegmentally between sterna VII and VIII. Terminalia (Fig. 12): gonocoxite extending ventrally as convex lobe beyond of gonostylus; gonostylus stout, with unfused and compressed denticles, dorsally with setae on distal third, ventrally with a cluster of setae on the basal half. Cerci notched, each cercus with 4 strong setae and a few fine setae. Hypoproct shorter than cerci and aedeagus, bilobed, with a seta on each lobe. Parameres about half length of hypoproct. Aedeagus gradually tapering, acute apex, longer than cerci.

Mature larva (Figs 13-15): Cylindrical, yellow. Number and position of thoracic and abdominal spiracles as in other Asphondyliini (see Möhn 1961); 6 dorsal papillae present on all thoracic segments and abdominal segments I-VII, each with a seta; abdominal segment VIII with 2 dorsal lobes, each with a setose dorsal papilla. Sternal spatula bilobed (Fig. 13) with posterior portion about 3.6 times as wide as the base of the anterior free portion. Two groups of lateral papillae on all thoracic segments, the inner group of 2 setose papillae and the outer group of 2 setose and 1 asetose papillae. Two sternal papillae on each thoracic segment and 4 sternal papillae on abdominal segments I-VIII, all without setae and situated on slight swellings. Ventral papillae each with a seta on meso- and metathoracic segments and on abdominal segments I-VII. Anus situated ventrally, with simple opening and 4 asetose anal papillae (Fig. 14). Two 

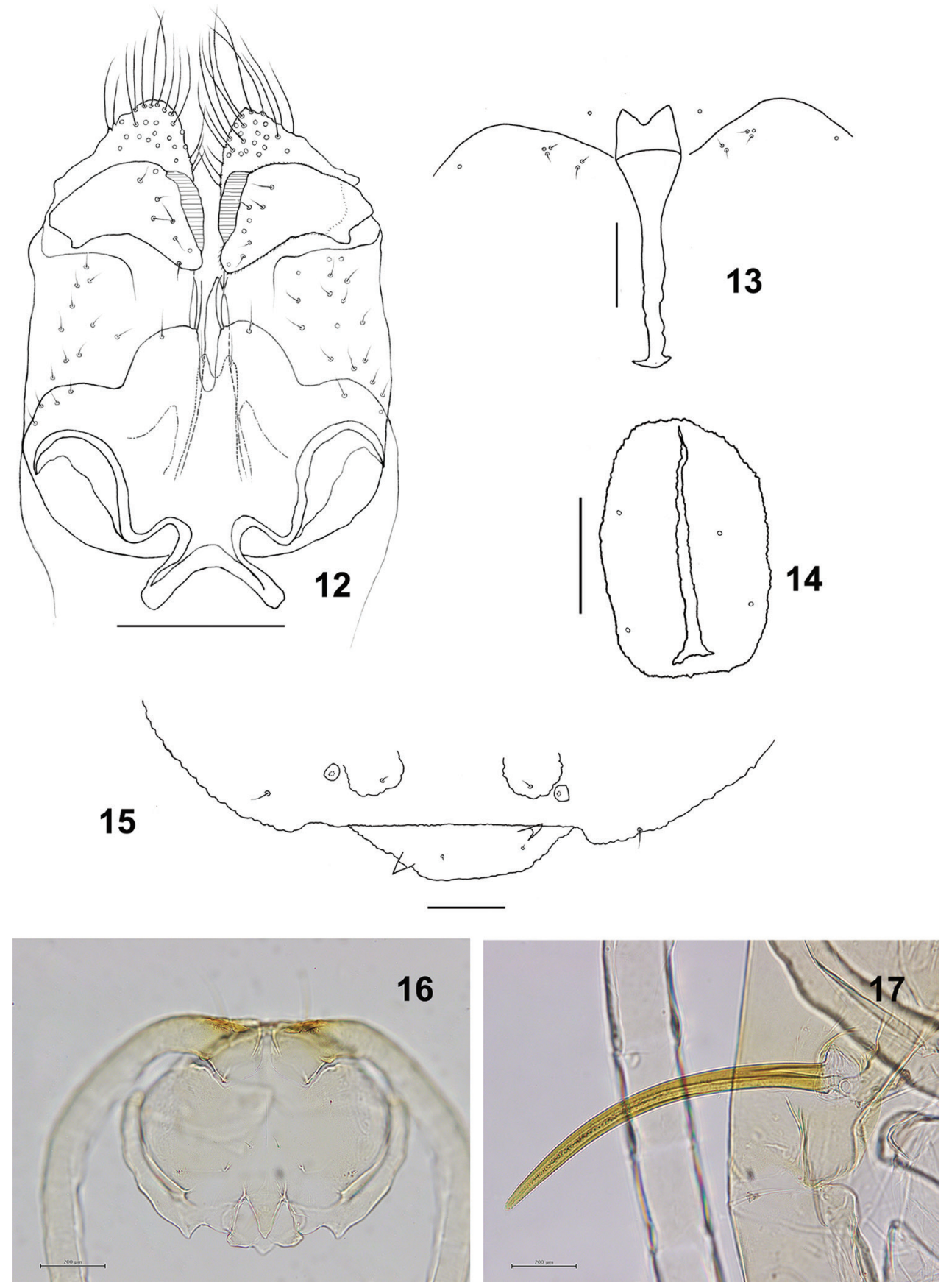

Figures I 2-I7. Schizomyia achyranthesae. I 2 Male terminalia I 3 Larval spatula 14 Larval anus 15 Terminal larval segment dorsally 16 Ventral view of pupal head 17 Pupal prothoracic spiracle. Scale bars: $50 \mu \mathrm{m}$ (I 2-I 5), $100 \mu \mathrm{m}(\mathbf{I 6}, \mathbf{I}$ ). 
pairs of pleural papillae present on all thoracic segments and abdominal segment VIII, and 3 pairs on abdominal segments I-VII. Terminal segment (Fig. 15) with 2 setose and 2 corniform terminal papillae.

Pupa (Figs 16, 17): Exuviae not pigmented except prothoracic spiracles and dorsal spines of abdomen. Antennal horns short; 2 pairs of cephalic papillae present, a pair with short seta; 2 pairs of lower facial papillae, a pair with seta; 3 lateral facial papillae present on each side, 1 with short seta, 2 without setae. Prothoracic spiracle, slightly curved, 23-29 $\mu \mathrm{m}$ long $(n=6)$, connected with trachea to the tip. Spiracles present on abdominal segments II-VI. Abdominal terga I-VIII each with anterior pair of trichoid sensilla and 2 pleural papillae; terga I-VII each with 3 pairs of dorsal papillae, only outermost pair with a seta; tergum VIII with a pair of dorsal papillae, each with a seta. Abdominal terga II-VIII each with 3-4 rows of spines on median third.

Distribution. Japan: Honshu, Shikoku, Kyushu (Yukawa and Masuda 1996) and Tanegashima Island (Yukawa et al. 2013).

Gall and life history. Schizomyia achyranthesae induces subglobular fruit galls on A. bidentata, 5.07-5.17 mm in diameter $(n=5)$ (Fig. 1) [Gall No. C-246 in Yukawa and Masuda (1996)]. Based on Yukawa and Masuda (1996) and present observations, each gall contains 1-13 chambers and each chamber contains a single larva. The galls appear in September. The mature larvae leave the galls between October and November and overwinter in the soil. The adults of $S$. achyranthesae emerge during the flowering season of the host plant in August and September.

Remarks. Schizomyia achyranthesae is distinguishable from the known Schizomyia species, except $S$. asteris and S. solidaginis, by its shallowly constricted male flagellomeres, lateral position of anterior pair of trichoid sensilla and presence of four larval terminal papillae, as well as two setose papillae in inner group of lateral papillae. $S$. achyranthesae can be separated from S. solidaginis based on the larval characters as follows: $S$. achyranthesae possesses a more elongated sternal spatula than $S$. solidaginis; the inner group of lateral papillae consists of two setose papillae in $S$. achyranthesae, but one setose and one asetose papillae in S. solidaginis; the anal opening is simple in S. achyranthesae, while branched in S. solidaginis. Then, S. achyranthesae can be separated from $S$. asteris by the following features: female cerci is less divided in S. achyranthesae; dorsal setae are present on the gonostylus in S. achyranthesae, but absent in A. asteris; and the gonocoxite is only slightly extends ventrally beyond the gonostylus in $S$. achyranthesae, and the larval anal opening is simple in S. achyranthesae while branched in S. asteris.

\section{Schizomyia diplocyclosae Elsayed \& Tokuda, sp. n.}

http://zoobank.org/C884D6A9-466D-45A8-9C63-A772B85E2539

Figs 18-29; Table $S 1$

Characters given in S. achyranthesae except for the following:

Etymology. The species name, diplocyclosae, is based on the generic name of the host plant, Diplocyclos palmatus (Cucurbitaceae). 

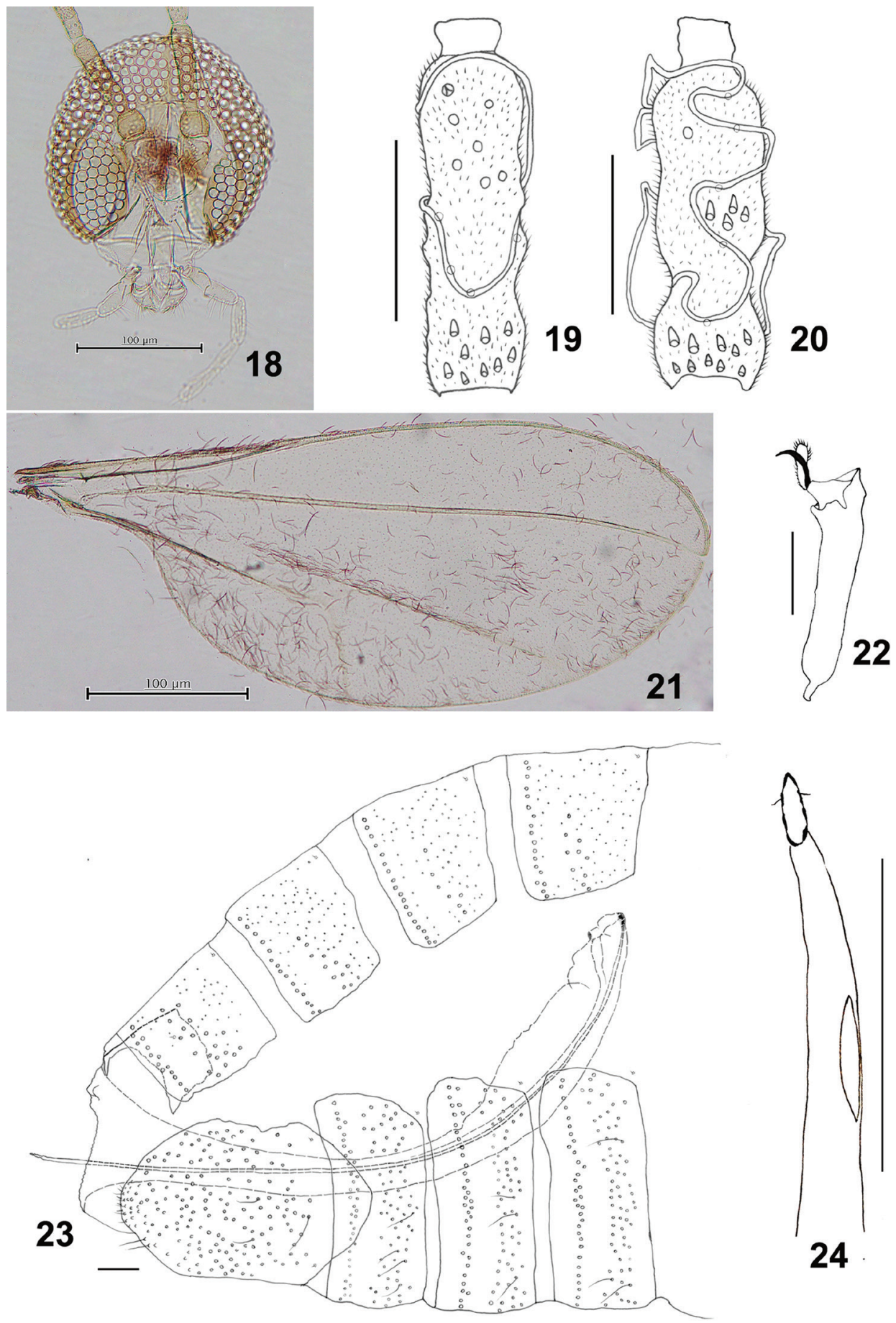

Figures I8-24. Schizomyia diplocyclosae. 18 Head 19 Ventral view of female flagellomere V 20 Dorsal view of male flagellomere V $\mathbf{2} \mathbf{I}$ Wing $\mathbf{2 2}$ Tarsomere $\mathrm{V}$ and acromere $\mathbf{2 3}$ Terminal part of female abdomen 24 Ovipositor apex Scale bars: $100 \mu \mathrm{m}(\mathbf{I 8}, \mathbf{1 9}), 50 \mu \mathrm{m}$ (20-24). 
Type material. Holotype: $1 \hat{\sigma}$ (KUEC): reared from a larva obtained from a flower bud gall on D. palmatus, collected from Hantagawa, Naha City, Okinawa Prefecture, Japan on 10.ii.2016, T. Ganaha-Kikumura leg., emerged on 14.iii.2016. Paratypes: All paratypes were reared from flower bud galls on D. palmatus in Japan. 4 larvae: collected from Gogayama, Nakijin Village, Okinawa Prefecture on 4.iii.2002, M. Tokuda leg., departed from galls on 9.iii.2002; 2 larvae: collected from Kinjo cho, Naha City, Okinawa Prefecture on 13.i.1977, S. Yamauchi leg.; 4 pupal exuviae: collected from Shuri, Naha City, Okinawa Prefecture, emerged in February 1977, S. Yamauchi leg.; 2 pupal exuviae, $3 \hat{\partial}$, 5ㅇ: same data as holotype; 5 pupal exuviae, 3ภ, 2q: collected from Hantagawa, Naha City, Okinawa Prefecture on 10.ii.2016, T. Ganaha-Kikumura leg., emerged on 15.iii.2016; 1 pupal exuviae: collected from Hantagawa, Naha City, Okinawa Prefecture on 10.ii.2016, T. Ganaha-Kikumura leg., emerged on 16.iii.2016; 1 pupal exuviae: collected from Hantagawa, Naha City, Okinawa Prefecture on 10.ii.2016, T. Ganaha-Kikumura leg., emerged on 21.iii.2016.

Description. Head (Fig. 18): Fronto-clypeus with 17-24 setae $(n=6)$. Palpus: first segment ca $38.3 \mu \mathrm{m}$, second 1.4 times as long as the first, third 1.3 as long as the second, fourth 1.5 as long as the third.

Thorax: Wing (Fig. 21) length 2.15-2.26 mm $(n=5)$ in female, 1.70-2.12 $(n=5)$ in male. Empodia slightly longer than tarsal claws (Fig. 22). Anepimeral setae 11-18 $(n=8)$; mesanepisternum scales 20-38 $(n=8)$; lateral scutum setae 26-48 $(n=8)$. Lengths of leg segments as in Suppl. material 1: Table S1.

Female abdomen (Figs 23, 24): Posterior margin of tergite VIII with a pair of slightly developed dorsal lobes. Sternite VII about 2.5 times as long as preceding sternites. Ovipositor: distal protrusible needle-like portion about 3 times as long as sternite VII.

Male abdomen: Terminalia (Fig. 25): Gonostylus dorsally with several setae on distal half.

Mature larva: Sternal spatula with posterior portion about 2.8 times as wide as the base of the anterior free portion (Fig. 26). Larval anus with 2 asetose anal papillae. Pupa (Figs 28, 29): Prothoracic spiracle 280-310 $\mu \mathrm{m}$ long $(n=6)$.

Distribution. Japan: Kikaijima Island and Okinawa-honto Island (Yukawa and Masuda 1996).

Gall and life history. Schizomyia diplocyclosae induces subglobular and pale green flower bud galls on D. palmatus, about $6-10 \mathrm{~mm}$ in diameter. Each gall consists of 10-45 chambers and each chamber contains a single larva [Gall No. C-409 in Yukawa and Masuda (1996)]. Galls become mature between December and March and larvae depart from galls to drop to the ground. The adults of $S$. diplocyclosae emerge in February and March when the larvae were reared under laboratory temperature (Yukawa and Masuda 1996, present data). Similar flower bud galls were found on Melothria liukiuensis Nakai (Cucurbitaceae) and considered to be induced by this species or a closely related one (Yamauchi et al. 1982, Yukawa and Masuda 1996). 

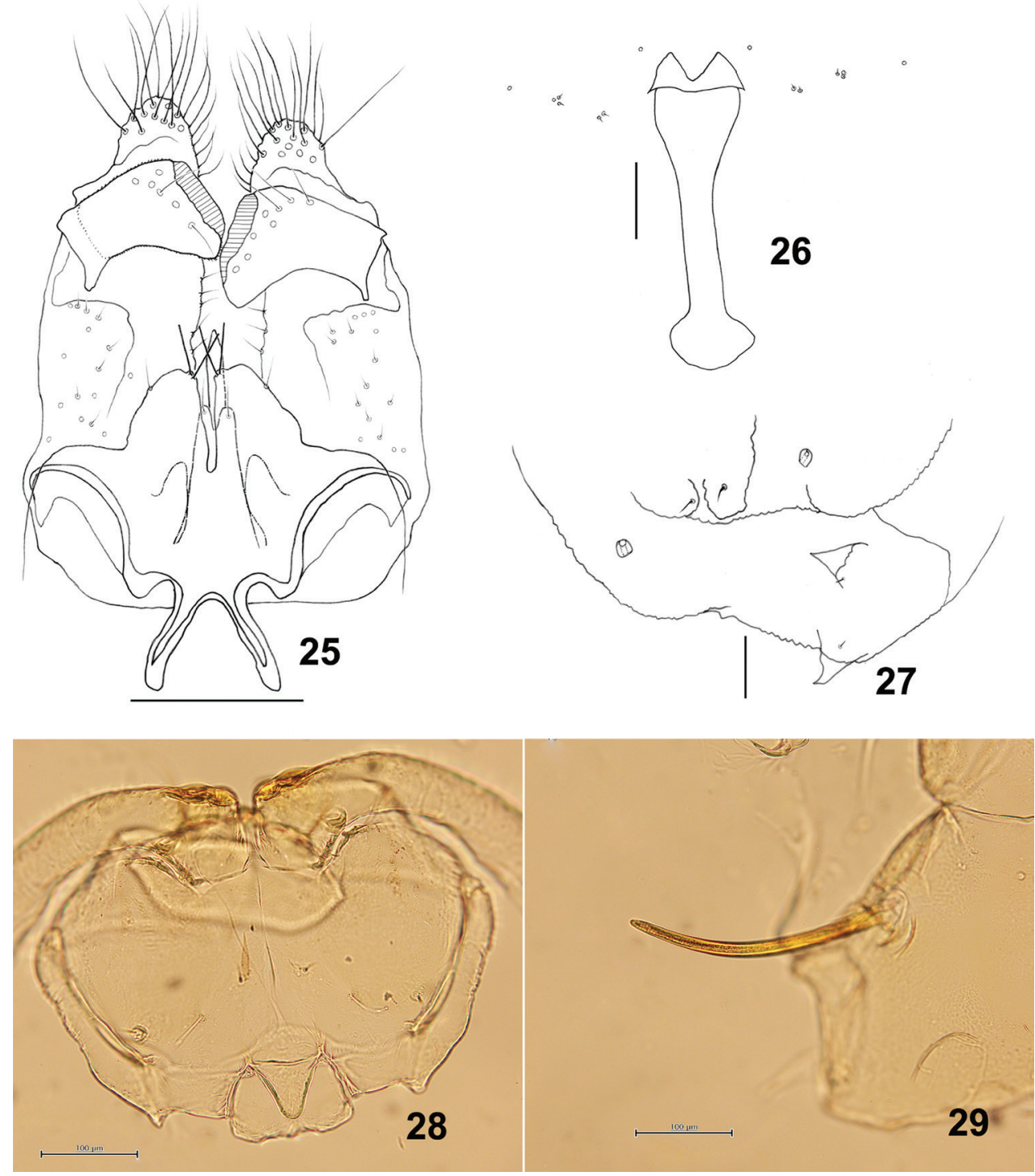

Figures 25-29. Schizomyia diplocyclosae. 25 Male terminalia 26 Larval spatula 27 Terminal larval segments dorsally $\mathbf{2 8}$ Ventral view of pupal head 29 Prothoracic spiracle in pupa. Scale bars: $50 \mu \mathrm{m}(\mathbf{2 5 - 2 7})$, $100 \mu \mathrm{m}(\mathbf{2 8 , 2 9})$.

Remarks. Schizomyia diplocyclosae is morphologically very similar to S. achyranthesae but differs from it by the following characters: S. diplocyclosae has a shorter ovipositor (protrusible needle-like-portion three times as long as sternite VII while four times as long in $S$. achyranthesae), less developed dorsal lobes on the posterior margin of female tergite VIII, gonocoxite more pointed posteroapically, empodia longer than claws and larva with only two anal papillae (four in S. achyranthesae). 


\section{Schizomyia castanopsisae Elsayed \& Tokuda, sp. n.}

http://zoobank.org/30620DFD-56AD-4C7D-B1FE-035383F80721

Figs 30-42; Table S2

Characters as in S. achyranthesae except for the following:

Etymology. The species name, castanopsisae, is based on the generic name of the host plant, Castanopsis sieboldii (Fagaceae).

Type material. Holotype: $1 \hat{\jmath}$ (KUEC): reared from a larva obtained from an inflorescence gall on C. sieboldii by A. K. Elsayed, collected from Hachijojima Island on 6.xii.2014, T. Kikuchi leg., emerged on 24.ii.2015. Paratypes: All paratypes were reared by A. K. Elsayed from inflorescence galls on C. sieboldii in Japan. 2 larvae: collected from Hachijojima Island on 6.xii.2014, T. Kikuchi leg., departed from galls on 22.xii.2014; 5 larvae: collected from Hachijojima Island on 6.xii.2014, T. Kikuchi leg., departed from galls on 25.xii.2014; 6 pupal exuviae, 2 ,, $3{ }^{\hat{0}}$ : collected from Shikinejima Island on 10.xii.2014, M. Tokuda leg., emerged between 24.i-20.ii.2015; 3

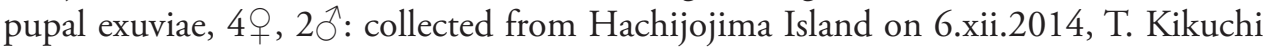
leg., emerged between 20.ii-5.iii.2015.

Description. Head (Fig. 30): Fronto-clypeus with 10-16 setae $(n=6)$. Palpus: first segment ca $43 \mu \mathrm{m}$, second 1.4 times as long as the first, third 1.5 as long as the second, fourth 1.2 as long as the third.

Thorax: Wing (Fig. 33) length 2.04-2.74 $\mathrm{mm}(n=6)$ in female, $2.04-2.56 \mathrm{~mm}(n=$ $4)$ in male. Anepimeral setae 8-15 $(n=8)$; mesanepisternum scales 15-26 $(n=7)$; lateral scutum setae 15-27 $(n=8)$. Lengths of leg segments as in Suppl. material 1: Table S2.

Female abdomen (Figs 35, 36): Sternite VII about 3 times as long as preceding. Ovipositor: protrusible needle-like portion about 3.3 as long as sternite VII.

Male abdomen: Terminalia (Figs 37, 38): Gonocoxite length about 3.3 times as long as gonostylus.

Mature larva: Sternal spatula (Fig. 39) with posterior portion about 2.8 times as wide as the base of the anterior free portion. Anus opening branched (Fig. 40).

Pupa (Fig. 42): Prothoracic spiracle 280-330 $\mu \mathrm{m}$ long $(n=6)$.

Distribution. Japan: The Izu Islands (from Niijima to Aogashima) (Tokuda et al. 2012a, b, 2013, 2015, Tokuda and Kawauchi 2013a), Kyushu (Kagoshima and Miyazaki Prefectures) (Nagai 2010, Tokuda and Kawauchi 2013b), Tanegashima Island (Yukawa et al. 2013) and Okinawa-honto Island (Yamauchi et al. 1982).

Gall and life history. Castanopsis sieboldii inflorescences galled by S. castanopsisae are rather irregularly swollen, $5.7-15.7 \mathrm{~mm}$ in diameter and $6.2-30.9 \mathrm{~mm}$ in length (Fig. 2) [Gall No. C-163 in Yukawa and Masuda (1996)]. Each gall consists of up to 30 chambers and each chamber contains a single larva. Mature larvae of $S$. castanopsisae left the galls collected in the Izu Islands in December within few days after the collection. Larvae were kept with soil in the laboratory and adults emerged the following January, February and March.

Remarks. Schizomyia castanopsisae is morphologically close to S. asteris, S. achyranthesae and S. diplocyclosae. Schizomyia castanopsisae can be separated from S. asteris by a 


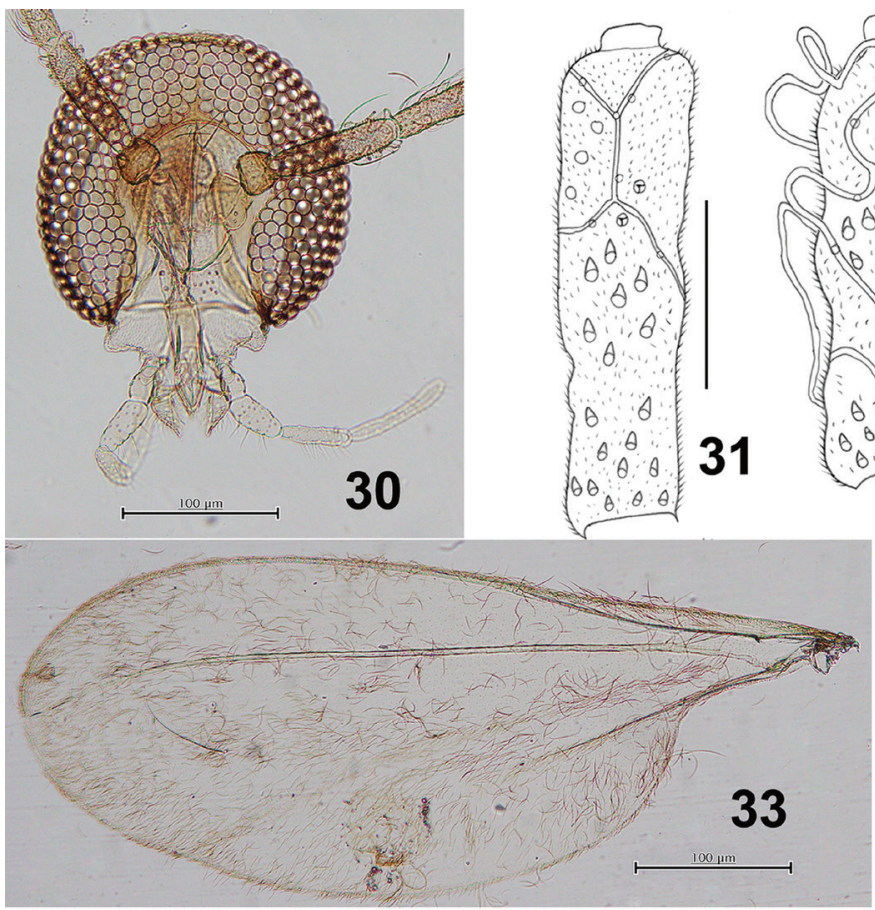

34
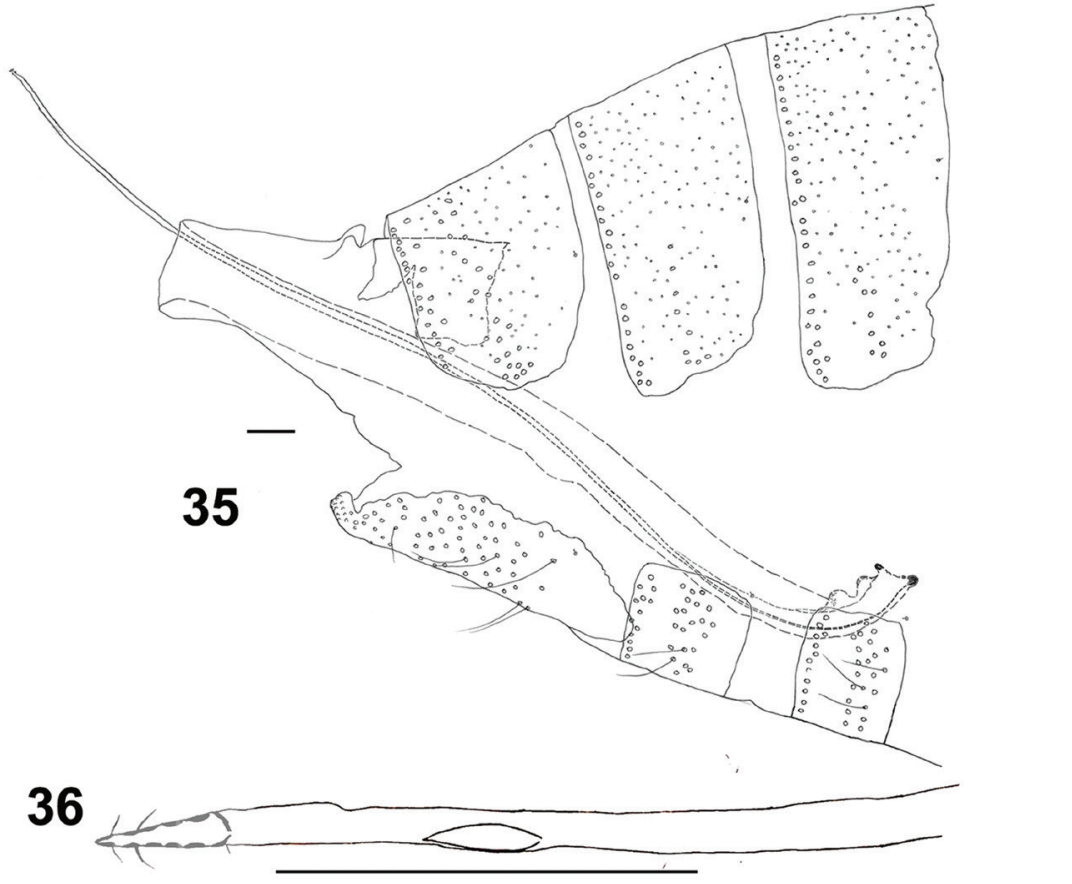

Figures 30-36. Schizomyia castanopsisae. $30 \mathrm{Head}$ 3 I Ventral view of female flagellomere V 32 Ventral view of male flagellomere V $\mathbf{3 3}$ Wing $\mathbf{3 4}$ Tarsomere $\mathrm{V}$ and acromere $\mathbf{3 5}$ Terminal part of female abdomen 36 Ovipositor apex. Scale bars: $50 \mu \mathrm{m}(\mathbf{3}$ I, 32, 34-36), $100 \mu \mathrm{m}(\mathbf{3 0}, \mathbf{3 3})$. 

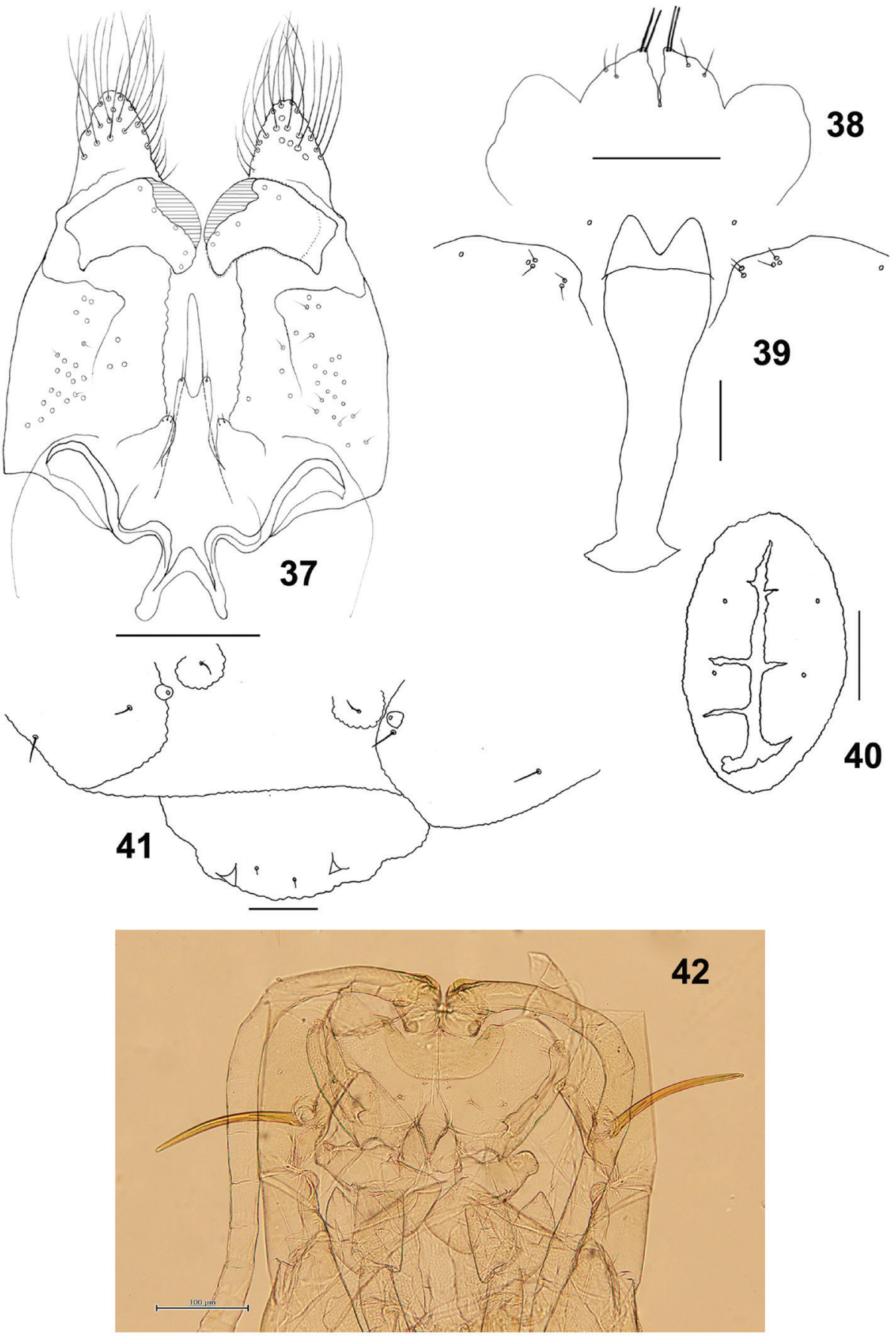

Figures 37-42. Schizomyia castanopsisae. 37 Male terminalia 38 Male cerci 39 Larval spatula 40 Larval anus $4 \mathbf{I}$ Terminal larval segments dorsally $\mathbf{4 2}$ Ventral view of pupal head and thorax. Scale bars: $50 \mu \mathrm{m}$ (37-4I), $100 \mu \mathrm{m}$ (42). 
shorter ovipositor (protrusible needle-like portion 3.3 times as long as sternite VII, while 5.7 times in S. asteris), the presence of dorsal setae on the gonostyli, and the tooth of gonostylus, which extends more dorsally than in that of $S$. asteris; from $S$. achyranthesae by a shorter ovipositor (four times as long as sternite VII in S. achyranthesae), more posteroapically pointed gonocoxite, and branched anal opening of larva; and from $S$. diplocyclosae by shorter empodia than tarsal claws (empodia are as long as claws in S. diplocyclosae) and the number of larval anal papillae (four in S. castanopsisae while two in S. diplocyclosae).

\section{Schizomyia usubai Elsayed \& Tokuda, sp. n.} http://zoobank.org/ACDD6BD7-7BAD-4330-8A79-03066DACA3F1 Figs 43-55; Table S2

Characters as in S. achyranthesae except for the following:

Etymology. The species name, usubai, honors the late Mr Shigeshi Usuba who reared adults of this species for the first time.

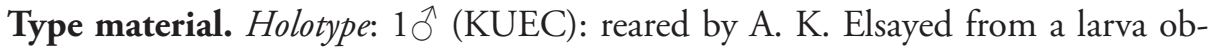
tained from a fruit gall on T. asiaticum, collected from Torinosu, Tanabe City, Wakayama Prefecture, Japan, I. Matoba leg., emerged on 22.v.2017. Paratypes: All paratypes were reared from fruit galls on T. asiaticum in Japan. 4 larvae: collected from Mount Takakuma, Kagoshima Prefecture in 1969, J. Yukawa leg.; 4 larvae: galls collected from Imuta Lake-side, Kedouin, Satsuma-sendai City, Kagoshima Prefecture on 2.xi.1978, S. Sako leg.; 4 pupal exuviae, $2 \hat{O}, 2$ : : collected from Torinosu, Tanabe City, Wakayama Prefecture, I. Matoba leg., reared by A. K. Elsayed, emerged on 18.v.2017; 2 pupal exuviae, 1 , $2 \hat{\circ}$ : same data as holotype.

Description. Head (Fig. 43): Compound eyes separated on vertex by a diameter of $0.0-0.5$ facets. Fronto-clypeal setae $15-16$ setae $(n=4)$. Palpus: first segment ca $53.5 \mu \mathrm{m}$, second about as long as the first, third 1.6 as long as the second, fourth 1.4 as long as the third.

Thorax: Wing (Fig. 46) length $2.03-2.34 \mathrm{~mm}(n=4)$ in female, $1.80-1.95 \mathrm{~mm}$ $(n=3)$ in male. Empodia as long as claws (Fig. 47). Anepimeral setae 10-20 $(n=4)$; mesanepisternum scales 17-40 $(n=4)$; lateral scutum setae 19-27 $(n=4)$. Lengths of leg segments as in Suppl. material 1: Table S2.

Female abdomen (Figs 48, 49): Sternite VII about 2.6 times as long as preceding. Ovipositor: protrusible needle-like portion about 4.5 as long as sternite VII.

Male abdomen: Terminalia (Fig. 50): Gonocoxite with developed, pointed apical lobe extending beyond gonostylus.

Mature larva: Sternal spatula (Fig. 51) with posterior portion about 3.5 times as wide as the base of the anterior free portion. Anus with branched opening (Fig. 52).

Pupa (Figs 54, 55): Prothoracic spiracle 250-350 $\mu \mathrm{m}$ long $(n=6)$.

Distribution. Japan: The Izu Islands (Tokuda et al. 2012b, 2013, Tokuda and Kawauchi 2013) Honshu, and Kyushu (Yukawa and Masuda 1996). 

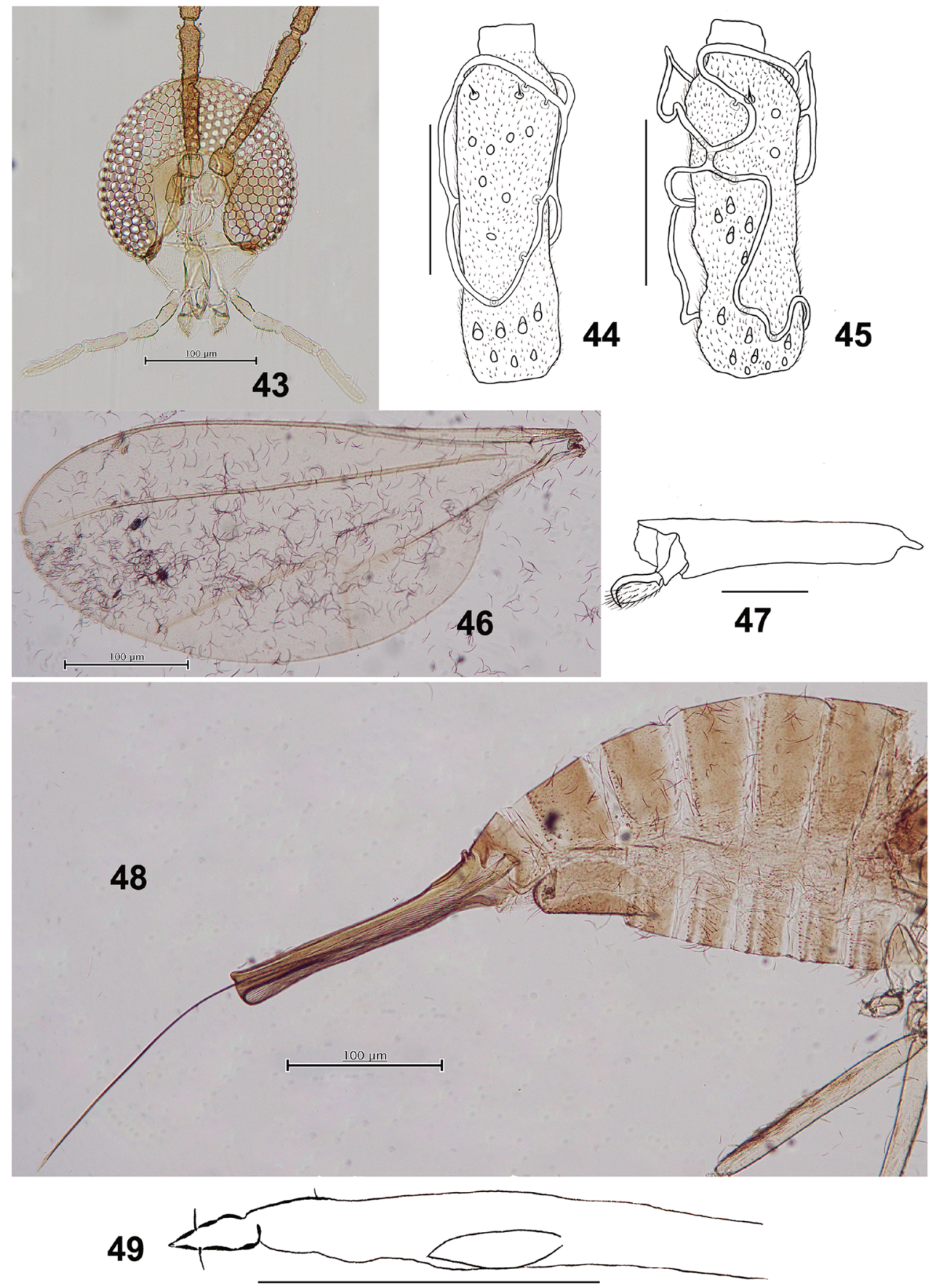

Figures 43-49. Schizomyia usubai. 43 Head 44 Ventral view of female flagellomere V 45 Ventral view of male flagellomere V $\mathbf{4 6}$ Wing $\mathbf{4 7}$ Tarsomere V and acromere $\mathbf{4 8}$ Terminal part of female abdomen

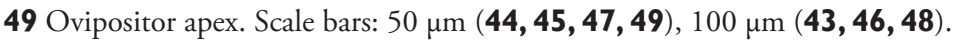



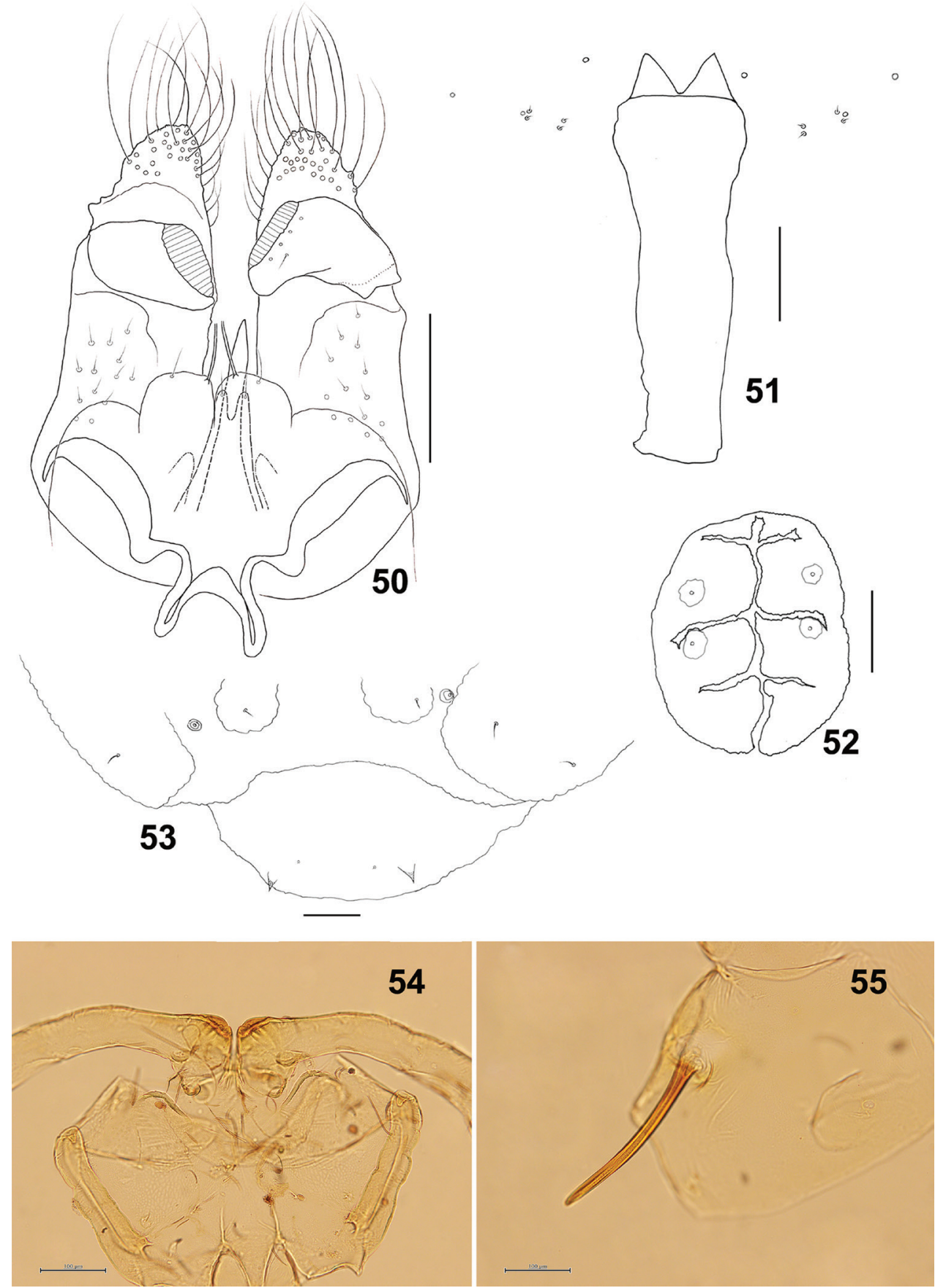

Figure 50-55. Schizomyia usubai. 50 Male terminalia $\mathbf{5}$ I Larval spatula $\mathbf{5 2}$ Larval anus $\mathbf{5 3}$ Terminal larval segments dorsally $\mathbf{5 4}$ Ventral view of pupal head $\mathbf{5 5}$ Pupal prothoracic spiracle. Scale bars: $50 \mu \mathrm{m}(\mathbf{5 0 - 5 3}), 100 \mu \mathrm{m}(\mathbf{5 4 , 5 5})$. 
Gall and life history. The normal fruit of Trachelospermum asiaticum (Apocynaceae) is V-shaped, consisting of a pair of very long and thin seed pods. When the fruits are galled by $S$. usubai, the apical parts of the fruit become fused and swollen, more or less cat-bell shaped (Fig. 3), about $12-18 \mathrm{~mm}$ in diameter and $27 \mathrm{~mm}$ in length [Gall No. D-033 in Yukawa and Masuda (1996)]. Each gall consists of 10-25 chambers and each chamber contains 10-25 larvae. Galls mature between late September and October and the larvae depart from galls to overwinter in soil. The adults of S. usubai emerge between late April and July (Yukawa 1978; Yukawa and Masuda 1996; present study). Similar galls probably induced by this species were found on Trachelospermum gracilipes Hook. f. var. kiukiuense (Hatus.) Kitam. on Tanegashima Island (Yukawa et al. 2013).

Remarks. Schizomyia usubai is close to S. asteris, S. achyranthesae, S. diplocyclosae and S. castanopsisae. Schizomyia usubai can be distinguished from S. asteris by a shorter ovipositor (protrusible needle-like portion about 4.5 times as long as sternite VII, while 5.5 times in $S$. asteris), longer empodia, and the presence of dorsal setae on gonostyli; from $S$. achyranthesae and $S$. diplocyclosae by a longer ovipositor (four and three times as long as sternite VII in $S$. achyranthesae and $S$. diplocyclosae, respectively), longer empodia, and branched opening of the larval anus. In addition, larva of $S$. usubai has four anal papillae, but two in $S$. diplocyclosae. Schizomyia castanopsisae is very similar to S. usubai, but can be separated by a shorter ovipositor (protrusible needle-like portion about 3.3 times as long as sternite VII, while 4.5 times in $S$. usubai), longer empodia, and less compressed circumfila of female flagellomeres.

\section{Schizomyia paederiae Elsayed \& Tokuda, sp. n.}

http://zoobank.org/DE35F88A-484D-45CE-9BC2-4356E0A1DE97

Figs 56-67; Tables S3

Characters as in S. achyranthesae except for the following:

Etymology. The species name, paederiae, is based on the generic name of the host plant, Paederia foetida (Rubiaceae).

Type material. Holotype: $1{ }^{\widehat{\lambda}}$ (KUEC): reared from a larva obtained from a flower bud gall on P. foetida, collected from Misawa, Ogori City, Fukuoka Prefecture, Japan, K. Matsunaga leg., emerged between 11-15.viii.2017. Paratypes: All paratypes were reared from flower bud galls on $P$. foetida in Japan. 11 larvae: collected from Nishinoomote, Nishinoomote City, Kagoshima Prefecture, on 24.ix.2014, K. Ogata leg.; 4 pupal exuviae, 20, 7 우 : same data as holotype.

Description. Head (Fig. 56): Compound eyes separated on vertex by a diameter of $0.0-1.5$ facets, eye bridge consist of 6-7 facets long. Fronto-clypeus with 11-13 setae $(n=4)$. Palpus: first segment ca $28.6 \mu \mathrm{m}$, second 1.3 times as long as the first, third 1.4 as long as the second, fourth 1.2 as long as the third.Male flagellomeres with deep basal constriction and elongated necks (Fig. 58). 

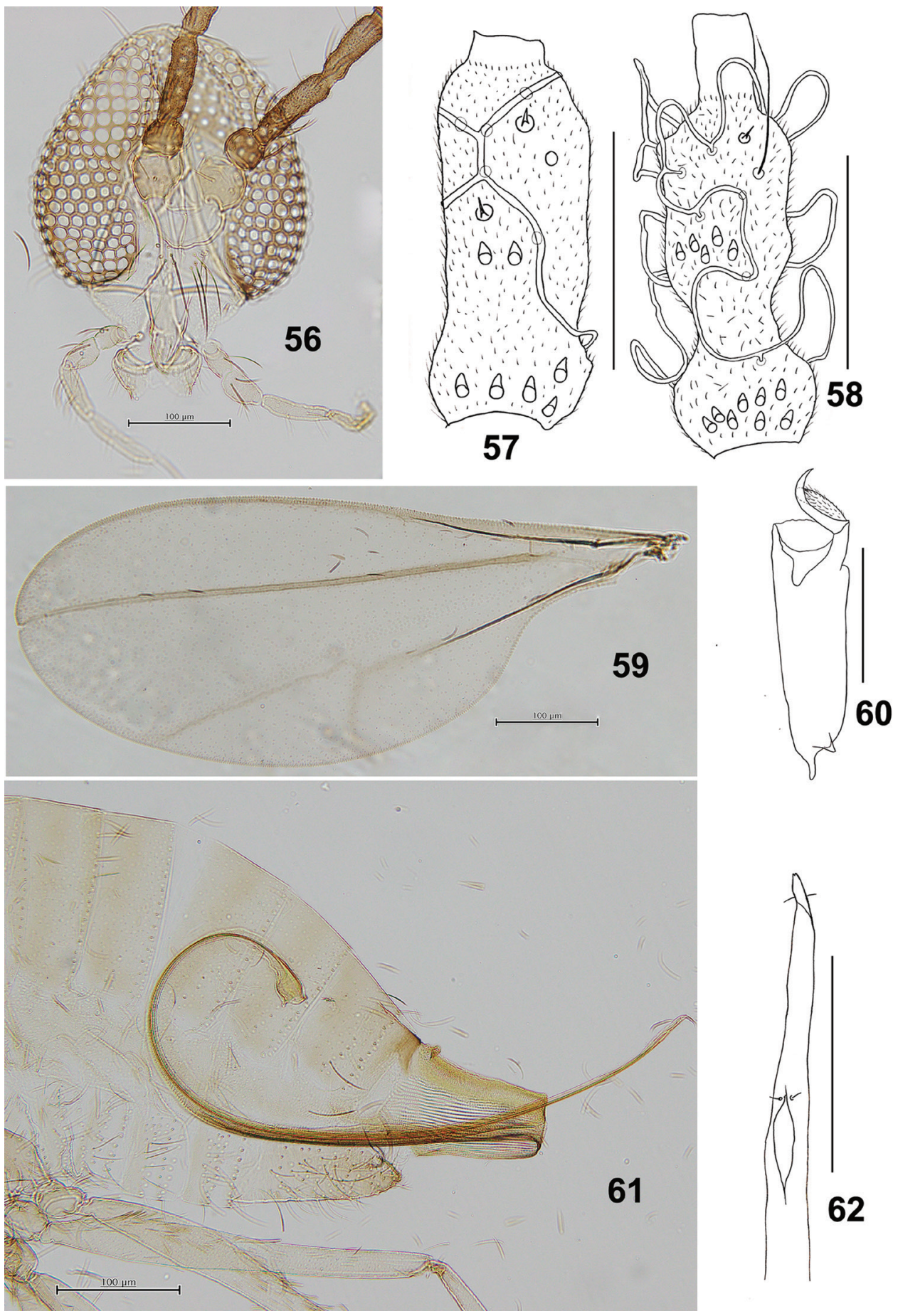

Figures 56-62. Schizomyia paederiae. 56 Head 57 Dorsal view of female flagellomere V 58 Dorsal view of female flagellomere V 59 Wing $\mathbf{6 0}$ Tarsomere V and acromere $\mathbf{6 I}$ Terminal part of female abdomen $\mathbf{6 2}$ Ovipositor apex. Scale bars: $50 \mu \mathrm{m}(\mathbf{5 7}, \mathbf{5 8}, \mathbf{6 0}, \mathbf{6 2}), 100 \mu \mathrm{m}(\mathbf{5 6}, \mathbf{5 9}, \mathbf{6 I})$. 
Thorax: Wing (Fig. 59) length 1.16-1.57 mm $(n=5)$ in female, 1.04-1.36 mm $(n$ $=3)$ in male. Anepimeral setae 9 or $10(n=5)$; mesanepisternum scales 5-10 $(n=6)$; lateral scutum setae 23-28 $(n=5)$. Empodia as long as tarsal claws (Fig. 60). Lengths of leg segments as in Suppl. material 1: Table S3.

Female abdomen (Figs 61, 62): Anterior pair of trichoid sensilla situated medially on abdominal sternites II-VI; sternite VII about 3.4 times as long as preceding sternites. Ovipositor: protrusible needle-like portion about 4.8 times as long as sternite VII.

Male abdomen: Anterior pair of trichoid sensilla situated medially on sternites II-VI and laterally on sternite VIII, sternite VIII with scattered setae. Terminalia (Fig. 63): Gonostylus dorsally with several setae on distal half, with unfused and compressed denticles.

Mature larva: Abdominal segment VIII with 2 setose dorsal papillae. Posterior portion of sternal spatula about 3.3 times as wide as the base of the anterior free portion (Fig. 64); 2 groups of lateral papillae present on all thoracic segments, each consisting of 2 setose and 1 asetose papillae. Terminal segment with 8 terminal papillae, consisting of 4 setose, 2 asetose and 2 corniform ones (Fig. 65).

Pupa (Figs 66, 67): Prothoracic spiracle 230-290 $\mu \mathrm{m}$ long $(n=4)$.

Distribution. Japan: Honshu, Shikoku, Kyushu, and Yakushima Island (Yukawa and Masuda 1996).

Gall and life history. Schizomyia paederiae induces flower bud galls on $P$. foetida. Basal parts of the galled flower buds are swollen, 3.0-5.6 $\mathrm{mm}$ in diameter and 4.0-6.1 $\mathrm{mm}$ in length (Fig. 4) [Gall No. D-037 in Yukawa and Masuda (1996)]. Galls are single-chambered and each gall contains 1-10 larvae. The larvae depart from mature galls from late August to September and overwinter in the soil. The adults of $S$. paederiae emerge in early August when the flower buds are available on the host plant (Yukawa and Masuda 1996).

Remarks. Schizomyia paederiae is distinguishable from other Schizomyia species, except four Russian species, i.e. S. calathidiphaga, S. clematidis, S. spiraeae, and S. veronicastrum, by its deeply constricted male flagellomeres (Kovalev 1964; Fedotova 2002). Firstly, the adults of $S$. paederiae differs from $S$. calathidiphaga by a slightly longer ovipositor (protrusible needle-like portion about 4.8 times as long as sternite VII, while 4.5 times in S. calathidiphaga), longer empodia (empodia are as long as claws in $S$. paederiae, but shorter in S. calathidiphaga), the position of gonostylus tooth (mostly covering only the apical margin in $S$. paederiae, but on the posteroapical margin in $S$. calathidiphaga), and the arrangement of papillae on the larval terminal segment (the two asetose terminal papillae are situated more posteriorly in $S$. paederiae, while more anteriorly in $S$. clathidiphaga). Then, the adults of $S$. paederiae can be separated from S. clematidis, S. spiraeae and S. veronicastrum by a longer neck of male flagellomere III, which is about 0.25 as long as node in $S$. paederiae but about 0.15 as long as node in other species, the position of gonostylus tooth (mostly covering the apical margin in $S$. paederiae, but on the posteroapical margin in the other species), and a much narrower hypoproct than $S$. clematidis. 

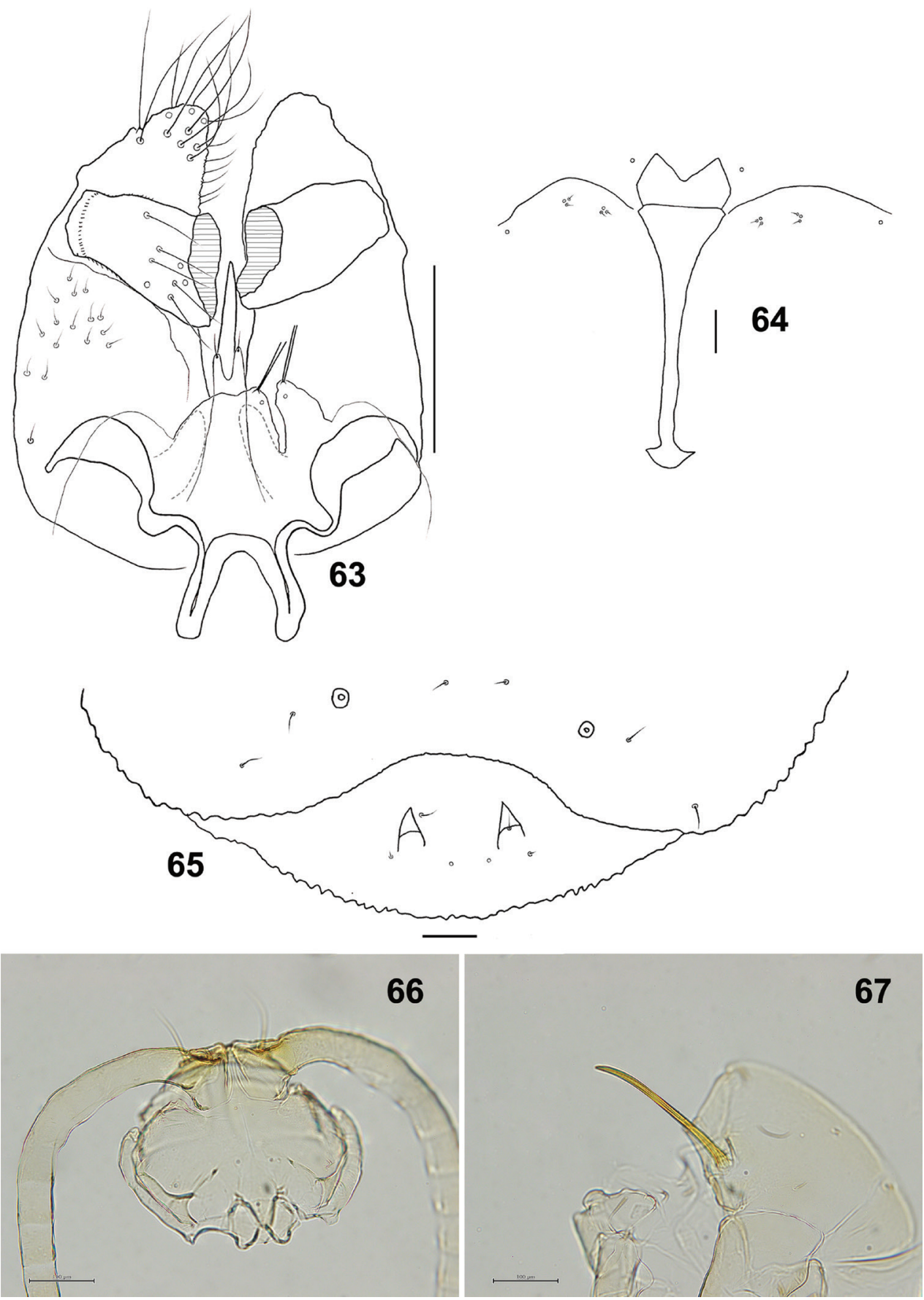

Figures 63-67. Schizomyia paederiae. 63 Male terminalia 64 Larval spatula 65 Terminal larval segments dorsally 66 Ventral view of pupal head 67 Pupal prothoracic spiracle. Scale bars: $50 \mu \mathrm{m}(\mathbf{6 3 - 6 5})$, $100 \mu \mathrm{m}(66,67)$. 


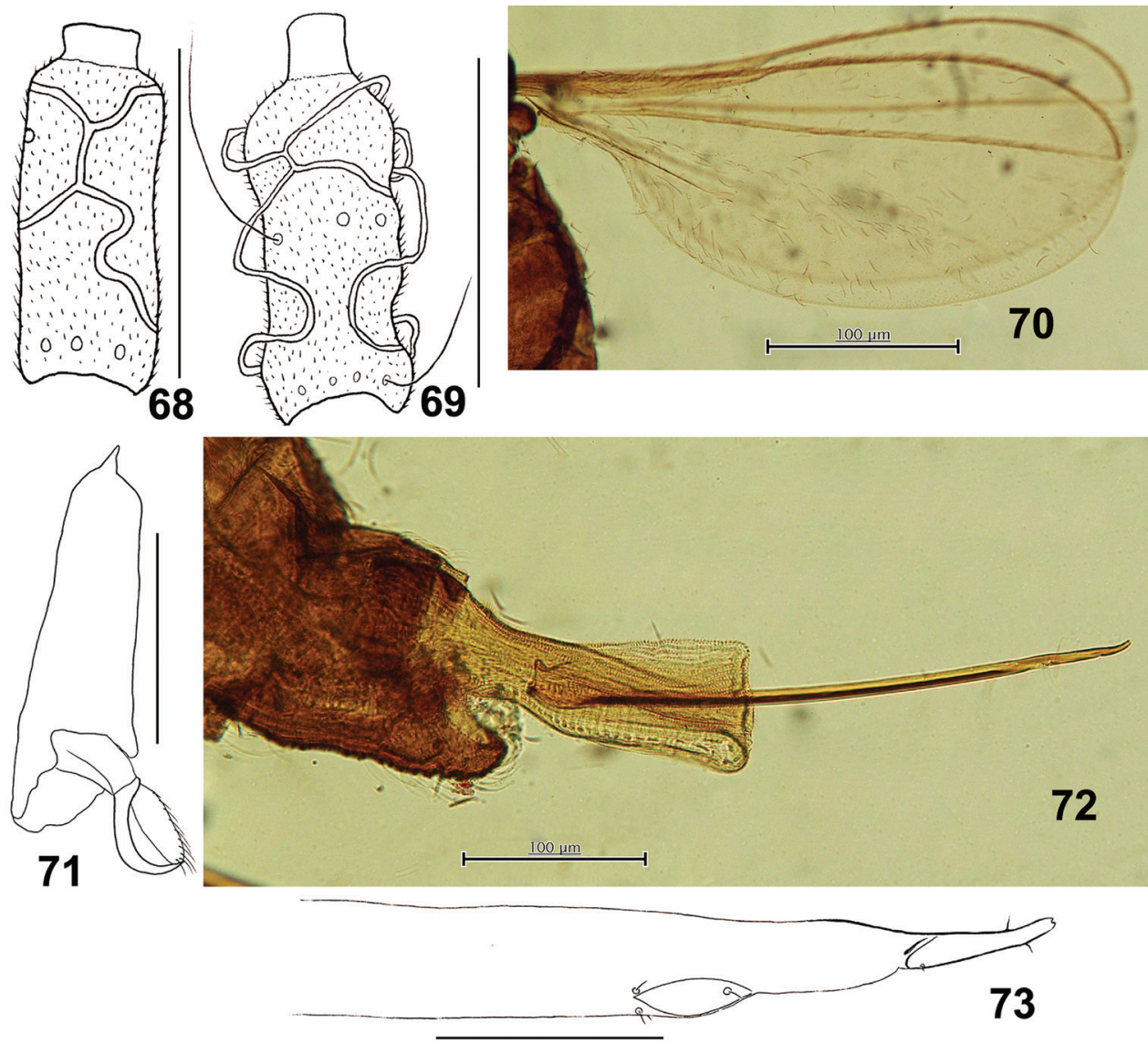

Figures 68-73. Schizomyia galiorum. 68 Lateral view of female flagellomere V 69 Lateral view of male flagellomere V $\mathbf{7 0}$ Wing $\mathbf{7 I}$ Tarsomere V and acromere $\mathbf{7 2}$ Terminal part of female abdomen showing the ovipositor 73 Ovipositor apex. Scale bars: $50 \mu \mathrm{m}(\mathbf{6 8 , 6 9 , 7 1 , 7 3 ) , ~} 100 \mu \mathrm{m}(\mathbf{7 0 , 7 2})$.

\section{Schizomyia galiorum Kieffer, 1889}

Figs 68-76; Table S3

Characters as in $S$. achyranthesae except for the following:

Material examined. 2ð, 39 (Mamaev collection: slide no. B1-251369): collected from Rybatskij, Lithuania on 19.vii.1969; 1 , 1 pupal exuviae (J. J. Kieffer’s specimen in Felt collection).

Description. Head: Compound eyes with rounded facets; facets on vertex and eye bridge unobservable because the specimens mounted laterally. Palpus: first segment ca $23.4 \mu \mathrm{m}$, second 1.6 times as long as the first, third 1.4 as long as the second, fourth 1.4 as long as the third.

Thorax: Wing (Fig. 70) length $1.33-1.55 \mathrm{~mm}(n=2)$ in male, $1.93 \mathrm{~mm}(n=1)$ in female; $R_{5}$ joining $C$ just before wing apex. Empodia as long as claws (Fig. 71). 

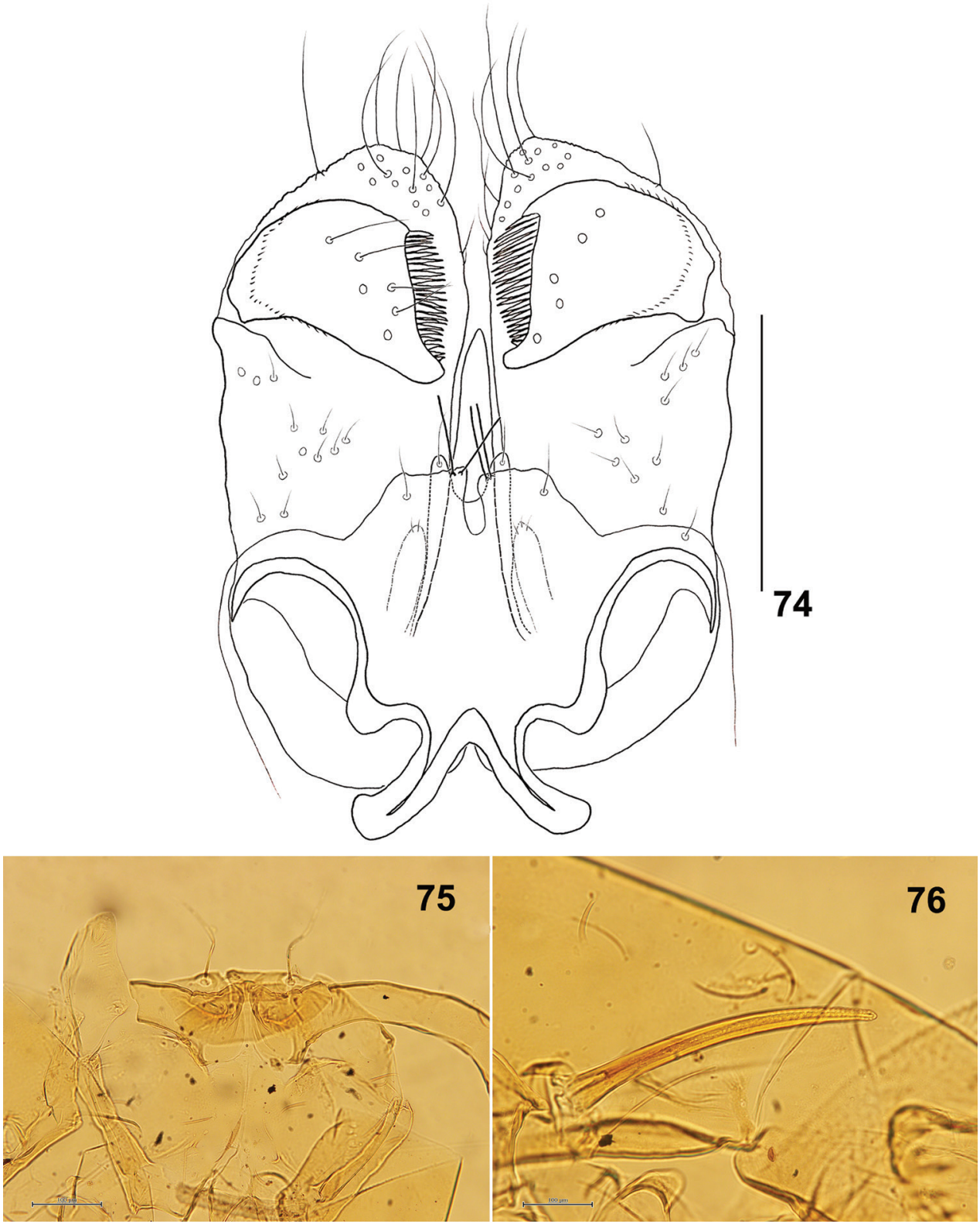

Figure 74-76. Schizomyia galiorum. 74 Male terminalia 75 Ventral view of pupal head 76 Pupal prothoracic spiracle. Scale bars: $50 \mu \mathrm{m}(\mathbf{7 4}), 100 \mu \mathrm{m}(\mathbf{7 5}, \mathbf{7 6})$.

Anepimeral setae 9-15 $(n=5)$; mesanepisternum scales 14-18 $(n=4)$; lateral scutum setae 17-37 $(n=5)$. Lengths of leg segments as in Suppl. material 1: Table S3.

Female abdomen: Posterior margin of tergite VIII without dorsal lobes. Sternites with median pair of trichoid sensilla. Sternite VII about twice as long as VI. Ovipositor (Figs 72, 73): protrusible needle-like portion short, about 1.9 times as long as sternite VII; cerci fused, with few fine setae (Fig. 73). 
Male abdomen: Sternites with median pair of trichoid sensilla. Sternite VII with two posterior rows of setae. Terminalia (Fig. 74): Gonocoxite with slightly developed apical lobe. Gonostylus with several setae on distal half dorsally, with group of setae on the basal half ventrally, and with distinctive unfused denticles. Hypoproct slightly longer than cerci.

Mature larva: Sternal spatula bilobed, the anterior free portion slightly wider than the posterior portion (Kieffer 1889). Two groups of lateral papillae present on each side of the spatula, each group of 2 setose and 1 asetose papillae. Terminal segment with 6 setose and 2 corniform terminal papillae (Möhn 1955).

Pupa (Figs 75, 76): Antennal horns slightly developed. Prothoracic spiracle 240 $\mu \mathrm{m}$ long $(n=1)$.

Distribution. Widespread Europe, Algeria and Kazakhstan (Gagné and Jaschhof 2017).

Remarks. This species is distinguished from eastern Holarctic congeners by the distinctly short ovipositor, the absence of dorsal lobes on the posterior margin of female tergite VIII, and the conjunction of wing vein $\mathrm{C}$ with $\mathrm{R}_{5}$ before wing apex.

\section{Schizomyia patriniae Shinji, 1938 comb. rev.}

Figs 77-85; Table $S 4$

Schizomyia patriniae Shinji, 1938: 372.

Asphondylia partriniae Shinji, 1944: 376, missp. of patriniae.

Asteralobia patriniae (Shinji, 1938)

Characters as in S. achyranthesae except for the following:

Material examined. All obtained from flower bud galls on Patrinia villosa (Valerianaceae) in Japan. 6 larvae: collected from Maruyama, Ojiya City, Niigata Prefecture on 12.x.1981, K. Yamagishi leg. 1ठ: Iozan, Kanazawa City, Ishikawa Prefecture on 17.x.1978, emerged on 22.iv.1979, J. Yukawa leg. 20, 4ㅇ, 2 pupal exuviae: collected from Kyuragi, Karatsu City, Saga Prefecture on 12.x.2015, M. Tokuda leg., emerged on 23.viii.2016, reared by A. K. Elsayed. $2 \hat{\jmath}, 3$ ㅇ, 2 pupal exuviae: collected from Kyuragi, Karatsu City, Saga Prefecture on 12.x.2015, M. Tokuda leg., emerged on 28.viii.2016, reared by A. K. Elsayed. 23: collected from Kyuragi, Karatsu City, Saga Prefecture on 12.x.2015, M. Tokuda leg., emerged on 29.viii.2016, reared by A. K. Elsayed.

Description. Head (Fig. 77): Compound eyes separated on vertex by a diameter of $0.25-1$ facets, eye bridge consist of 5-6 facets long. Fronto-clypeus with 15-20 setae $(n=9)$. Palpus: first segment ca $34.1 \mu \mathrm{m}$, second 1.4 times as long as the first, third 1.4 as long as the second, fourth segment 1.5 as long as the third.

Thorax: Wing (Fig. 80) length 1.83-2.09 $\mathrm{mm}(n=5)$ in female, $1.50-1.83 \mathrm{~mm}(n=$ $5)$ in male. Anepimeral setae 17-23 $(n=8)$; mesanepisternum scales 16-20 $(n=7)$; lateral scutum setae 32-46 $(n=8)$. Lengths of leg segments as Suppl. material 1: Table S4.

Female abdomen (Figs 82, 83): Median pair of trichoid sensilla present on sternites II-VII. Sternite VII about 3 times as long as preceding. Ovipositor: protrusible needlelike portion about 4.8 as long as sternite VII. 

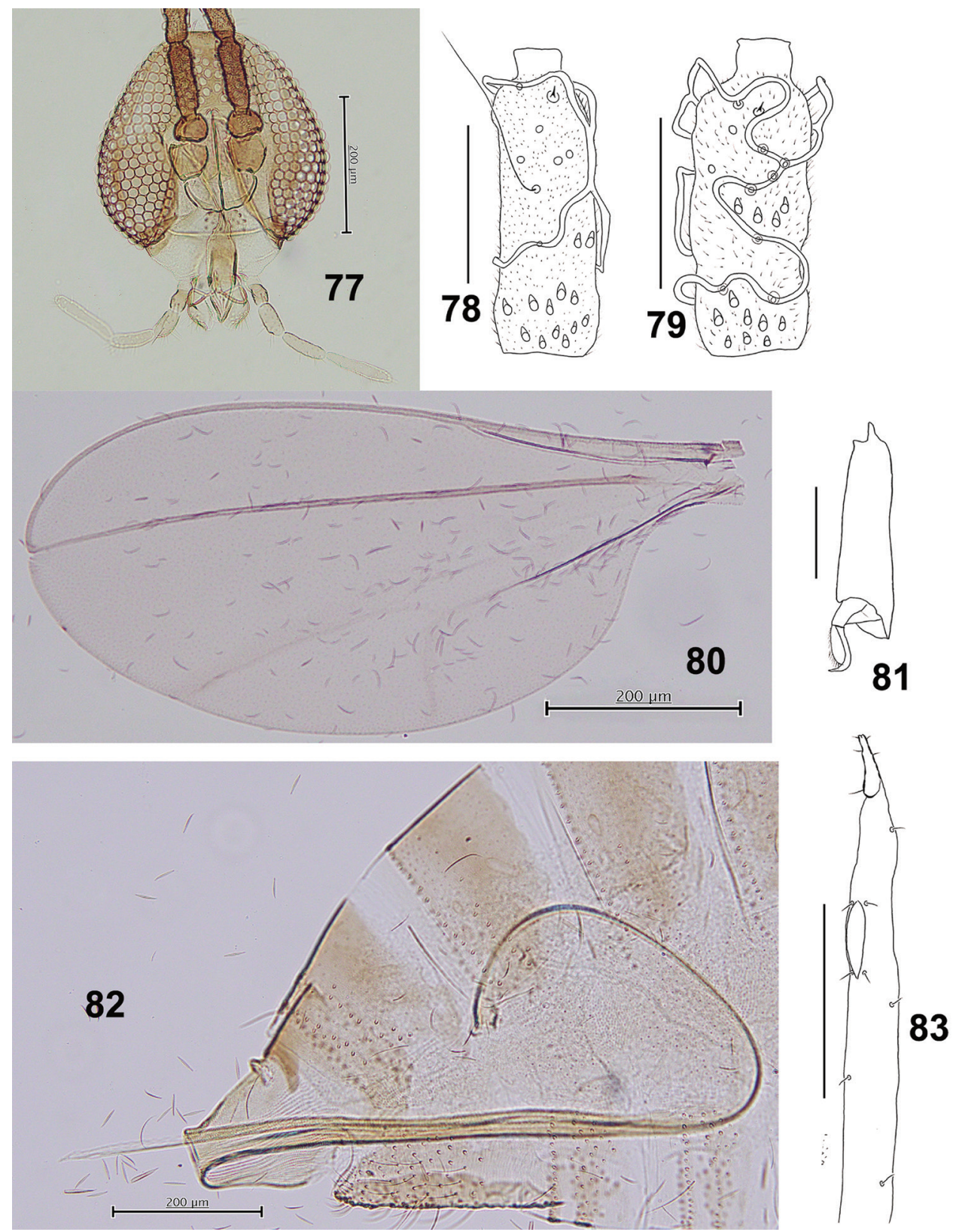

Figures 77-83. Schizomyia patriniae. $77 \mathrm{Head} \mathbf{7 8}$ Dorsal view of female flagellomere V $\mathbf{7 9}$ Ventral view of female flagellomere V $\mathbf{8 0}$ Wing $\mathbf{8 I}$ Tarsomere V and acromere $\mathbf{8 2}$ Terminal part of female abdomen 83 Ovipositor apex. Scale bars: $50 \mu \mathrm{m}(\mathbf{7 8 , 7 9 , 8 1 , 8 3 ) ,} 200 \mu \mathrm{m}(\mathbf{7 7 , 8 0 , 8 2})$.

Male abdomen: Trichoid sensilla present on sternites II-VIII in median position, except on VIII in lateral position. Terminalia (Fig. 84): Gonocoxite length about 3.3 times as long as gonostylus. Gonostylus with slim tooth in the dorsal and ventral views. 

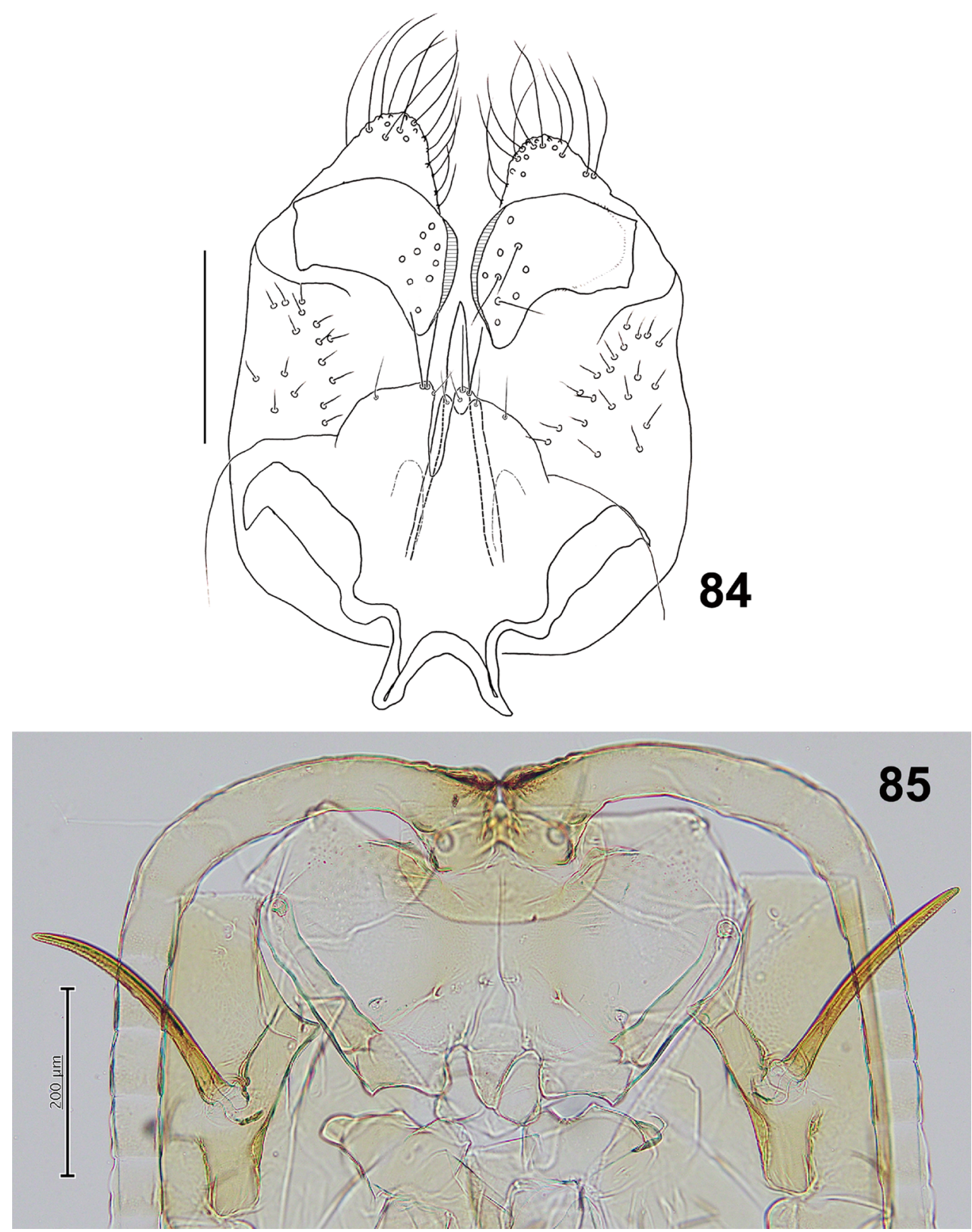

Figures 84-85. Schizomyia paederiae. 84 Male terminalia $\mathbf{8 5}$ Ventral view of pupal head and prothorax. Scale bars: $50 \mu \mathrm{m}$ (84), $200 \mu \mathrm{m}(\mathbf{8 5})$.

Mature larva: Abdominal segment VIII without dorsal papillae. Two groups of lateral papillae on all thoracic segments, each consisting of 2 setose and 1 asetose papillae. The terminal segment with 1 setose and 6 asetose terminal papillae (Yukawa 1983). Pupa (Fig. 85): Prothoracic spiracle 260-290 $\mu \mathrm{m}$ long $(n=5)$. 
Distribution. Japan: Hokkaido, Honshu and Shikoku (Yukawa and Masuda 1996).

Remarks. This species had been described by Shinji (1938) under the genus Schizomyia. Then, Yukawa (1983) combined the species with Asteralobia because of its shallowly constricted male flagellomeres. Because Asteralobia is synonymized under Schizomyia in this paper, S. patriniae is combined again with Schizomyia.

Schizomyia patriniae is distinguishable from known Schizomyia species, except three species that were previously treated as Asteralobia and newly combined here under Schizomyia, i.e. S. sasakii, S. soyogo, and S. humuli, by the presence of shallow constrictions on male flagellomeres and the absence of corniform papillae on the terminal larval segment. S. patriniae can be easily separated from S. sasakii, S. soyogo and S. humuli based on the number of papillae on the larval terminal segment: $S$. patriniae possesses two setose and six asetose terminal papillae, but $S$. sasakii and S. soyogo have only six setose terminal papillae, and $S$. humuli has four setose terminal papillae.

\section{Schizomyia asteris (Kovalev, 1964) comb. $\mathrm{n}$.}

Figs 86-93; Table S4

\section{Asteralobia asteris Kovalev, 1964}

Characters as in S. achyranthesae except for the following:

Material examined. $2 \hat{\jmath}, 2$ : (Mamaev collection: slide no. B1-251363 \& 251364), galls collected from Aster sp. in Kedrovaja Pad reserve, Russian Far East on 28.viii.1964. 4 larvae: galls collected from $A$. tataricus in Smolyaninovo, Primorsky Territory, Russian Far East on 13.ix.2002, M. Tokuda leg. 6 larvae: galls collected from A. scaber in Smolyaninovo, Primorsky Territory, Russian Far East on 13.ix.2002, M. Tokuda leg.

Description. Head: Compound eyes with rounded facets; facets on the vertex and eye bridge unobservable. Palpus: first segment ca $34.5 \mu \mathrm{m}$, second 1.8 times as long as the first, third 1.2 as long as the second, fourth 1.1 as long as the third.

Thorax: Wing length $1.93 \mathrm{~mm}(n=1)$ in female, $1.55-2.02 \mathrm{~mm}(n=2)$ in male. Anepimeral setae 14-15 $(n=3)$; mesanepisternum scales 17-23 $(n=7)$; lateral scutum setae 23-29 $(n=4)$. Lengths of leg segments as in Suppl. material 1: Table S4.

Female abdomen: Ovipositor: protrusible needle-like portion about 5.7 times as long as sternite VII; cerci divided medially, with sclerotized margins and few setae (Fig. 89).

Male abdomen: Terminalia (Fig. 90): Gonocoxite with pointed apical lobe extending beyond gonostylus. Gonocoxite length about 3.5 times as long as gonostylus. Gonostylus without setae ventrally and dorsally.

Mature larva: Sternal spatula with posterior portion about 3.3 times as wide as the base of the anterior free portion (Fig. 91). Abdominal segment VIII with three dorsal lobes, the outer two each with 1 setose dorsal papilla (Fig. 92). Anus with branched opening, and 4 asetose anal papillae (Fig. 93).

Pupa: Prothoracic spiracle about $220 \mu \mathrm{m}$ long $(n=1)$.

Distribution. Russian Far East (Kovalev 1964; Tokuda et al. 2003). 

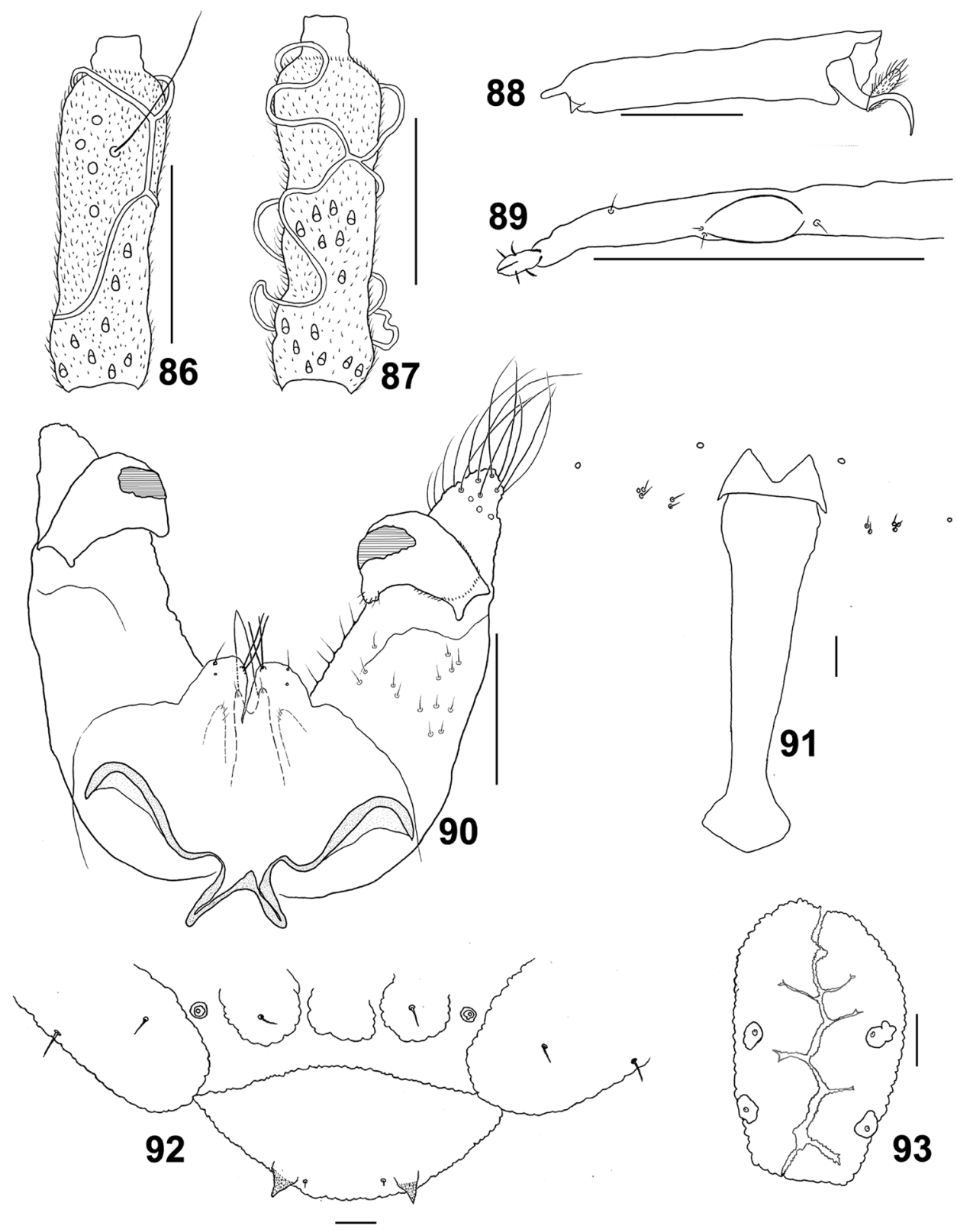

Figures 86-93. Schizomyia asteris. 86 Lateral view of female flagellomere V 87 Lateral view of male flagellomere V $\mathbf{8 8}$ Tarsomere V and acromere $\mathbf{8 9}$ Ovipositor apex $\mathbf{9 0}$ Male terminalia $\mathbf{9 I}$ Larval spatula 92 Terminal larval segments dorsally $\mathbf{9 3}$ Larval anus. Scale bar: $50 \mu \mathrm{m}$.

Remarks. Although Kovalev (1964) mentioned that $S$. asteris is closest to S. doellingeriae, Tokuda et al. (2003) showed that they are distinguishable by the number of lateral papillae, terminal papillae, and the shape of anal opening. 


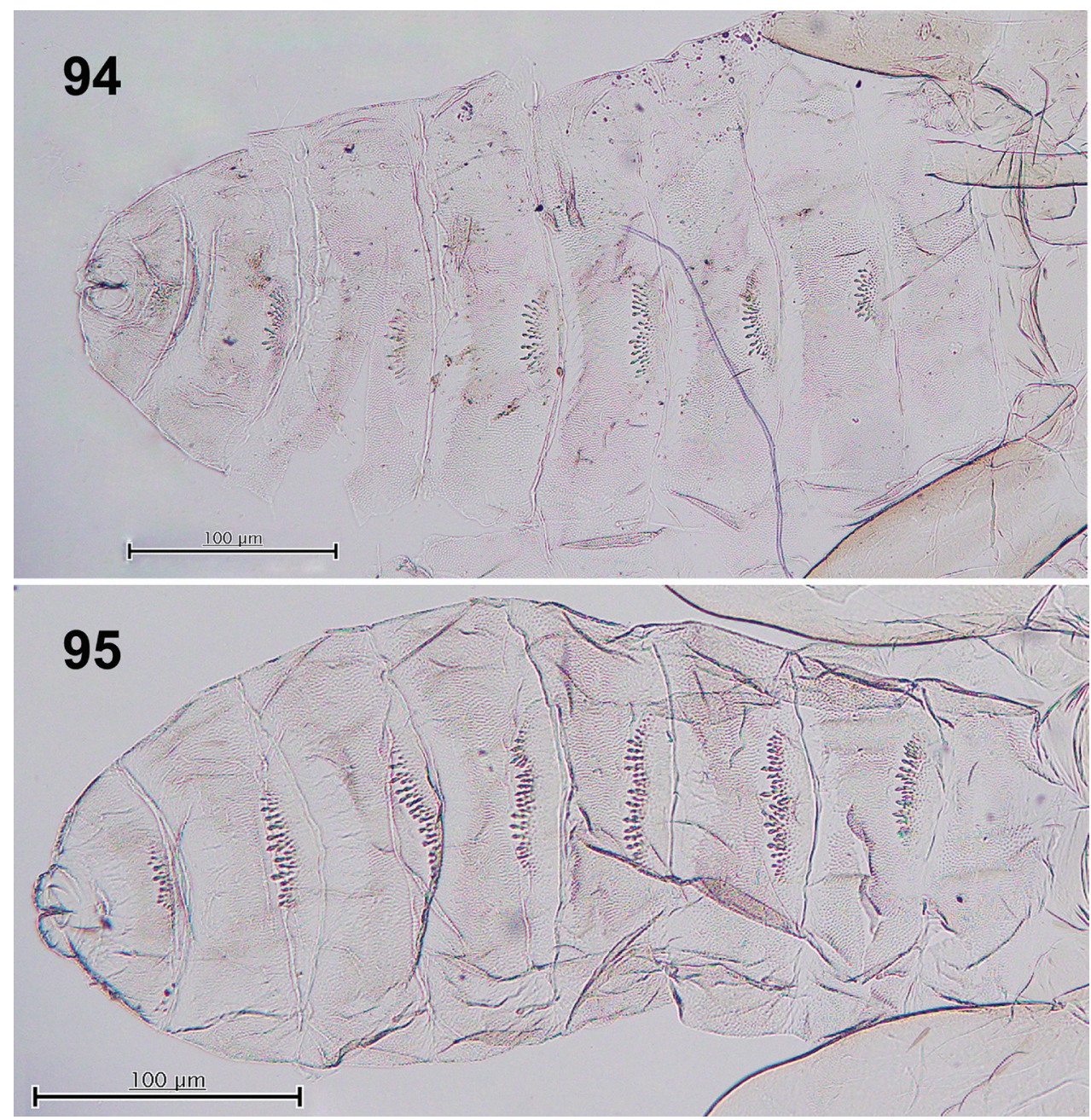

Figures 94-95. Dorsal view of pupal abdominal segments. 94 Schizomyia soyogo 95 Schizomyia sasaki. Scale bar: $100 \mu \mathrm{m}$.

\section{Taxonomic key to Schizomyia species in Japan}

$1 \quad$ Male flagellomeres deeply constricted (Fig. 58)

S. paederiae sp. $\mathbf{n}$.

- $\quad$ Male flagellomeres shallowly constricted (Fig. 7) 2

$2 \quad$ Trichoid sensilla present medially on adult sternites II-VI ..........................3

- $\quad$ Trichoid sensilla present laterally anterior to the sclerotized sternites II-VI in

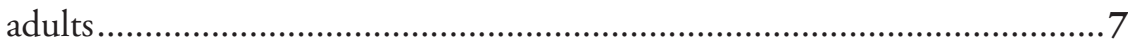

3 Larval terminal segment with 8 terminal papillae....................................... 4

- $\quad$ Larval terminal segment with fewer than 8 terminal papillae ........................5 
4 Terminal papillae of 2 corniform and 6 setose papillae (Tokuda et al. 2003: fig. 1A) S. doellingeriae

- $\quad$ Terminal papillae of 2 setose and 6 asetose (Yukawa 1983: fig. 4E)

S. paterinia

Terminal papillae made up of 4 setose papillae: 2 with long setae and 2 with tiny setae. S. humuli

- Terminal papillae made up of 6 setose papillae. 6

6 Pupal dorsal abdominal spines covering about $1 / 4$ of the upper area of terga II-VIII (Fig. 94) (see Tokuda et al. 2004 for full-description of the species).

- $\quad$ Pupal dorsal abdominal spines covering about $1 / 3$ of the upper area of terga II-VIII (Fig. 95) (see Tokuda et al. 2004 for full-description of the species)..

S. sasakii

Larval anal opening simple (e.g. Fig. 14). 8 Protrusible needle-like portion of ovipositor about 4 times as long as sternite VII (Fig. 10) S. achyranthesae sp. $\mathbf{n}$.

- $\quad$ Protrusible needle-like portion of ovipositor about 3 times as long as sternite VII (Fig. 23) S. diplocyclosae sp. $\mathbf{n}$. Protrusible needle-like portion of ovipositor about 3.3 times as long as sternite VII (Fig. 35)

S. castanopsisae sp. $\mathbf{n}$.

- $\quad$ Protrusible needle-like portion of ovipositor about 4.5 times as long as sternite VII (Fig. 49)

S. usubai sp. n.

\section{Molecular phylogenetic study}

The complete molecular dataset of COI and $12 \mathrm{~S}$ consisted of approximately $800 \mathrm{bp}$. The monophyly of Schizomyia was strongly supported with a 99\% bootstrap value, and the genus was divided into two main clades. One clade with a 55\% bootstrap support was subdivided into three subclades: one including S. galiorum, S. doellingeriae, S. humuli, S. patriniae and S. kovelavi; another including S. sasakii, S. soyogo, and S. paederia; and the third comprising $S$. buboniae. The second main clade contains six morphologically-close species: S. diplocyclosae, S. castanopsisae, S. achyranthesae, S. solidaginis, S. asteris and S. usubai, and gained a 95\% bootstrap support.

\section{Discussion}

In the present study, we showed that constricted male flagellomeres, the only character used to separate Asteralobia from Schizomyia (Kovalev 1964), can be also observed in the type species of Schizomyia, S. galiorum, and hence Asteralobia is synonymized here 


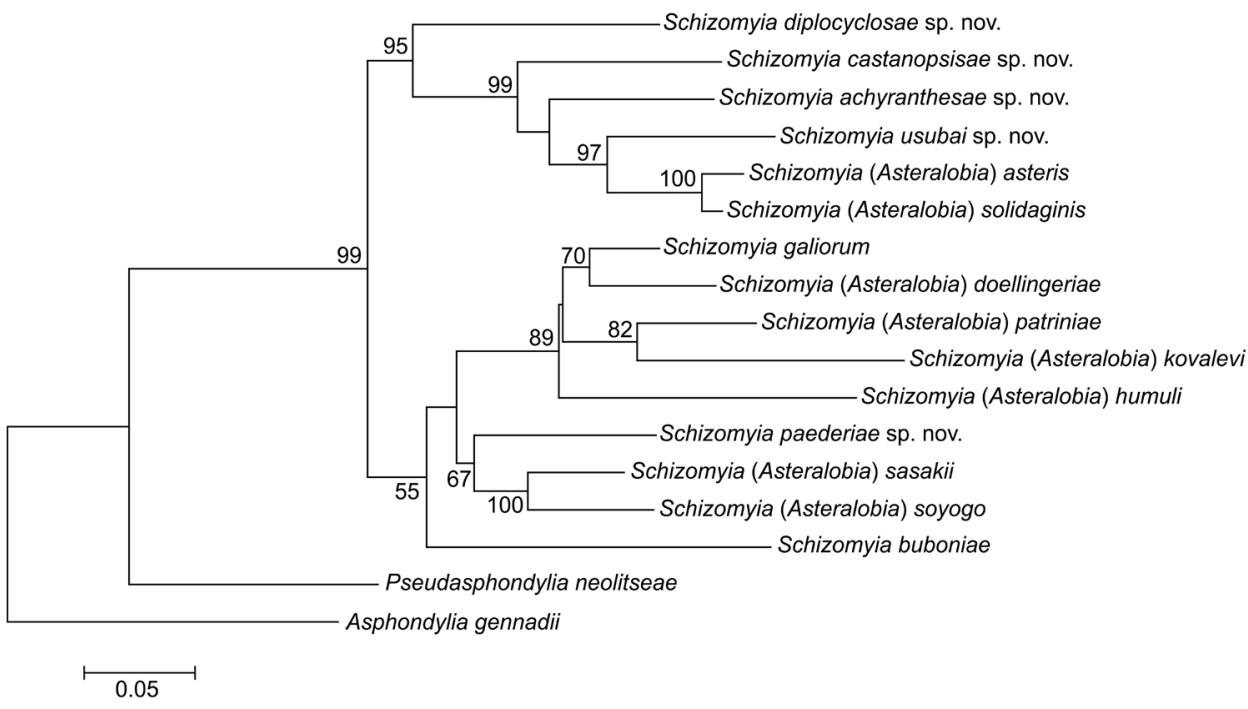

Figure 96. A phylogenetic reconstruction based on partial sequences of cytochrome oxidase subunit I (COI) and $12 \mathrm{~S}$ small ribosomal subunit genes. The topology and branch length were produced by the maximum likelihood method (note the scale bar). Bootstrap values are indicated at branches gaining more than $50 \%$ support ( $10^{3}$ replications).

under Schizomyia. Our molecular phylogenetic analysis strongly supported this conclusion with high bootstrap values.

Because of the broad definition of Schizomyia, which depends only on plesiotypic characters (Gagné and Marohasy 1997; Gagné 1994), some other genera of Schizomyiina, e.g., Metasphondylia, Placochela and Schizandrobia, are considered to fit easily into its definition (Gagné and Jaschhof 2017). Comprehensive taxonomic and molecular analyses including these genera are needed for further progress on the taxonomy of Schizomyia.

In the present study, six eastern Palearctic Schizomyia species, namely $S$. achyranthesae, S. asteris, S. diplocyclosae, S. castanopsisae, S. usubai and S. solidaginis, were shown to be close to each other and (although we have never examined the phylogenetic position of S. solidaginis) constructed a monophyletic clade in the molecular analysis. They differ from all known Schizomyia spp. by the laterally situated anterior pair of trichoid sensilla, which are present anterior to the sclerotized sternite. This character can be considered as derived because in other genera of Schizomyiina, the anterior pair of trichoid sensilla are usually located on the sternites. Future comprehensive taxonomic studies may treat these species as a natural cluster within Schizomyia.

Several important characters need to be re-evaluated in order to meet current taxonomic standards in many Schizomyia species. For example, the ovipositors of most known Schizomyia species were not described in detail, although they can be expected to be variable because of their adaptation for oviposition on different organs of hosts belonging to various, not related, families. Similarly, the pupa, which offers many diagnostic features for taxonomy in Schizomyiina (Möhn 1961), is still unknown and 
undescribed in many species, especially in those that develop in the soil and are not easily found. Descriptions of these unknown morphological features of Schizomyia species are essential to clarify the generic concept.

\section{Acknowledgments}

We thank R. J. Gagné (Systematic Entomology Laboratory, USDA, Washington, DC, USA) for his valuable comments on the manuscript. We also thank Y. Nagano (Analytical Research Center for Experimental Sciences, Saga University, Japan) for his careful assistance in molecular studies. We are grateful to T. Ganaha-Kikumura, A. Kita, T. Kikuchi, I. Matoba, K. Matsunaga, K. Ogata, S. Sako, K. Yamagishi, S. Yamauchi and M. Yukinari for collecting galls.

\section{References}

Darriba D, Taboada GL, Doallo R, Posada D (2012) jModelTest 2: more models, new heuristics and parallel computing. Nature Methods 9: 772. https://doi.org/10.1038/nmeth.2109

Elsayed AK, Ogata K, Kaburagi K, Yukawa J, Tokuda M (2017) A new Dasineura species (Diptera: Cecidomyiidae) associated with Symplocos cochinchinensis (Loureiro) (Symplocaceae) in Japan. Japanese Journal of Systematic Entomology 23: 81-86.

Elsayed AK, Uechi N, Yukawa J, Tokuda M (in press) Ampelomyia, a new genus of Schizomyiina (Diptera: Cecidomyiidae) associated with Vitis (Vitaceae) in the Palaearctic and Nearctic regions, with description of a new species from Japan. The Canadian Entomologist.

Elsayed AK, Shimizu-Kaya U, Itioka T, Meleng P, Yukawa J, Tokuda M (2018) A new genus and a new species of Schizomyiina (Diptera: Cecidomyiidae: Asphondyliini) inducing petiole galls on Macaranga bancana (Miq.) in Borneo, Malaysia. Zootaxa 4482: 188-196. https://doi.org/10.11646/zootaxa.4482.1.10

Fedotova ZA (2002) New species of gall midges (Diptera, Cecidomyiidae) from the Russian Far East. Far Eastern Entomologist 118: 1-35.

Folmer O, Black M, Hoew W, Lutz R, Vrijenhoek R (1994) DNA primers for amplification of mitochondrial cytochrome c oxidase subunit I from diverse metazoan invertebrates. Molecular Marine Biology and Biotechnology 3: 294-299.

Funk DJ, Futuyma DJ, Orti G, Meyer A (1995) Mitochondrial DNA sequences and multiple data sets: a phylogenetic study of phytophagous beetles (Chrysomelidae: Opharaella). Molecular Biology and Evolution 12: 627-640. https://doi.org/10.1093/oxfordjournals. molbev.a040242

Gagné RJ, Jaschhof M (2017) A Catalog of the Cecidomyiidae (Diptera) of the World (4 $4^{\text {th }}$ edn). Digital version, 762 pp. https://www.ars.usda.gov/ARSUserFiles/80420580/ Gagne_2017_World_Cat_4 ${ }^{\text {th }} \_$ed.pdf

Gagné RJ, Marohasy J (1997) A new species of Schizomyia Kieffer (Diptera: Cecidomyiidae) on rubber vine and other Asclepiadaceae in Madagascar. Australian Journal of Entomology 36: 15-18. https://doi.org/10.1111/j.1440-6055.1997.tb01424.x 
Gagné RJ, Menjivar R (2008) A new species of Schizomyia (Diptera: Cecidomyiidae), a pest of Fernaldia pandurata (Apocynaceae) in Central America. Proceedings of the Entomological Society of Washington 110: 384-291. https://doi.org/10.4289/07-053.1

Gagné RJ (1968) A taxonomic revision of the genus Asteromyia (Diptera: Cecidomyiidae).

Miscellaneous Publications of the Entomological Society of America 6: 1-40.

Gagné RJ (1989) The Plant-feeding Gall Midges of North America. Cornell University Press, Ithaca, New York, 356 pp.

Gagné RJ (1994) The Gall Midges of the Neotropical Region. Cornell University Press, Ithaca, New York, 352 pp.

Guindon S, Gascuel O (2003) A simple, fast and accurate method to estimate large phylogenies by maximum-likelihood. Systematic Biology 52: 696-704. https://doi. org/10.1080/10635150390235520

Kambhampati S, Smith PT (1995) PCR primers for the amplification of four insect mitochondrial gene fragments. Insect Molecular Biology 4: 233-236. https://doi. org/10.1111/j.1365-2583.1995.tb00028.x

Kieffer JJ (1889) Neue Beitrage zur Kenntniss der Gallmücken. Entomologische Nachrichten 15: 183-194.

Kieffer JJ (1913) Deux nouvelles cécidomyies d'Algérie. Bulletin de la Société d'Histoire Naturelle de l'Afrique du Nord 5: 90-92.

Kolesik P, Butterill PT (2015) New gall midges (Diptera: Cecidomyiidae) from Papua New Guinea. Austral Entomology 54: 79-86. https://doi.org/10.1111/aen.12095

Kovalev OV (1964) A review of the gall midges (Diptera, Itonididae) of the extreme south of the Soviet Far East. I. The supertribe Asphondylidi. Entomological Review 43: 215-228.

McAlpine JF, Peterson BV, Shewell GE, Teskey HJ, Vockeroth JR, Wood DM (1981) Manual of Nearctic Diptera, Vol. 1, Research Branch, Agriculture Canada, Ottawa, Monograph No. 27, 674 pp.

Möhn E (1955) Beiträge zur Systematik der Larven der Itonididae (=Cecidomyiidae, Diptera).

1. Teil: Porricondylinae und Itonidinae Mitteleuropas. Zoologica 105: 1-247.

Möhn E (1961) Neue Asphondyliidi-Gattungen (Diptera, Itonididae). Stuttgarter Beiträge zur Naturkunde 49: 1-14.

Nagai A (2010) Insect galls in Miyazaki Prefecture II. Nishimoro-no-Seibutsu 3: 7-38. [In Japanese]

Pantone DJ, Brown SM (1985) New host records for Schizomyia macrofila (Felt) (Diptera: Cecidomyiidae). Pan-Pacific Entomologist 61: 153. [Abstract].

Shinji O (1938) Two new species of gall-flies (Dipt.) from north-eastern Japan. Zoological Magazine 50: 371-374.

Shinji O (1944) Galls and Gall Insects. Shunyodo, Tokyo, 58 pp.

Simon C, Frati F, Beckenbach A, Crespi B, Liu H, Flook P (1994) Evolution, weighting, and phylogenetic utility of mitochondrial gene sequences and a compilation of conserved polymerase chain reaction primers. Annals of the entomological Society of America 87: 651-701. https://doi.org/10.1093/aesa/87.6.651 
Sousa LID, Maia VC (2007) A new species of Schizomyia (Diptera, Cecidomyiidae, Asphondyliini) associated with Tetrapterys phlomoides (Malpighiaceae). Iheringia. Série Zoologia 97: 311-313. https://doi.org/10.1590/S0073-47212007000300021

Tamura K, Stecher G, Peterson D, Filipski A, Kumar S (2013) MEGA6: Molecular Evolutionary Genetics Analysis Version 6.0. Molecular Biology and Evolution 30: 2725-2729. https://doi.org/10.1093/molbev/mst197

Tokuda M, Kawauchi K (2013a) Arthropod galls found on Toshima and Shikinejima Islands, the Izu Islands, Japan. Japanese Journal of Systematic Entomology 19: 261-274.

Tokuda M, Kawauchi K (2013b) Collection record of Castanopsis gall midge (Diptera: Cecidomyiidae) from Kagoshima Prefecture. Pulex 92: 616-617. [In Japanese]

Tokuda M, Harris KM, Yukawa J (2005) Morphological features and molecular phylogeny of Placochela Rübsaamen (Diptera: Cecidomyiidae) with implications for taxonomy and host specificity. Entomological Science 8: 419-427. https://doi.org/10.1111/j.14798298.2005.00141.x

Tokuda M, Matsuo K, Yukawa J (2012a) Insect galls found on Mikurajima and Aogashima, the Izu Islands, Tokyo, Japan. Japanese Journal of Entomology (New Series) 15: 75-84 [In Japanese with English summary].

Tokuda M, Matsuo K, Yukawa J (2012b) Insect galls found on Miyakejima and Hachijojima Islands, the Izu Islands, Tokyo, Japan. Esakia 52: 59-66.

Tokuda M, Kawauchi K, Kikuchi T, Iwasaki Y (2015) Arthropod galls newly found on the Izu Islands, Tokyo, Japan. Japanese Journal of Systematic Entomology 21: 363-365.

Tokuda M, Matsuo K, Kiritani K, Yukawa J (2013) Insect galls found on Ohshima, Kozushima and Niijima Islands, the Izu Islands, Tokyo, Japan. Makunagi, Acta Dipterologica 25: 1-16.

Tokuda M, Tabuchi K, Yukawa J, Amano H (2004) Inter- and intraspecific comparisons between Asteralobia gall midges (Diptera: Cecidomyiidae) causing axillary bud galls on Ilex species (Aquifoliaceae): species identification, host range, and mode of speciation. Annals of Entomological Society of America 97: 957-970. https://doi.org/10.1603/00138746(2004)097[0957:IAICBA]2.0.CO;2

Tokuda M, Yukawa J, Kuznetsov VN, Kozhevnikov AE (2003) Asteralobia gall midges (Diptera: Cecidomyiidae) on Aster species (Asteraceae) in Japan and the Russian Far East. Esakia 43: 1-10.

Yukawa J (1971) A revision of the Japanese gall midges. Memoirs of the Faculty of Agriculture, Kagoshima University 8: 1-203.

Yukawa J (1978) New midge galls from Kyushu. Memoirs of the Faculty of Agriculture, Kagoshima University 14: 93-101.

Yukawa J (1983) Redescriptions of three species of the genus Asteralobia (Diptera, Cecidomyiidae). Memoirs of the Faculty of Agriculture, Kagoshima University 19: 97-108.

Yukawa J, Masuda H (1996) Insect and mite galls in Japan in color. Zenkoku Nôson Kyôiku Kyôkai, Tokyo, 826 pp. [In Japanese with English explanations for color plates].

Yukawa J, Ogata K, Kaburagi K, Tokuda M (2013) Cecidomyiid galls found on Tanegashima Island. Satsuma 150: 48-61. [In Japanese] 


\section{Supplementary material I}

\section{Supplementary data}

Authors: Ayman Khamis Elsayed, Junichi Yukawa, Makoto Tokuda

Data type: measurements

Explanation note: Table S1. Length $(\mu \mathrm{m})$ of each leg segment in Schizomyia achyranthesae and S. diplocyclosae. Table S2. Length $(\mu \mathrm{m})$ of each leg segment in Schizomyia tokudai and S. usubai. Table S3. Length $(\mu \mathrm{m})$ of each leg segment in Schizomyia paederiae and S. galiorum. Table S4. Length $(\mu \mathrm{m})$ of each leg segment in Schizomyia patriniae and $S$. asteris.

Copyright notice: This dataset is made available under the Open Database License (http://opendatacommons.org/licenses/odbl/1.0/). The Open Database License $(\mathrm{ODbL})$ is a license agreement intended to allow users to freely share, modify, and use this Dataset while maintaining this same freedom for others, provided that the original source and author(s) are credited.

Link: https://doi.org/10.3897/zookeys.808.29679.suppl1 